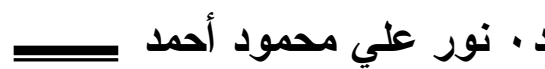

\title{
تطبيقات فقهية
}

\section{على جواز تغير الأحكام الاجتهادية}

د · نور علي محمود أحمد (")

المقدمة :

إن الحمد لله، نحمده ونستعينه، ونعوذ باله من شرور أنفسنا، ومن سيئات أعمالنا، من يهذه الله فهو المهتد، ومن يضلل فلن تجد لله وليَّا مرشدًا، و أشهر أن لا إله إلا الله وأن محمدًا عبده ورسوله، اللهم صل عِّ على سيدنا محمد، و على آله و أصحابه الطاهرين المطهرين، ومن اتَّعهم بإحسان إلى يوم الدين. وبعد: - و

فإن من أعظم الآيات التي ترشد إلى و اقعية الثريعة الإسلامية وقدرتها على البقاء و الخلود؛ أنها قامت على أسس وقو اعد متينة، تكفل لها الاستمر ار إلى ليوم الدين، حيث تستمد هذه القو اعد أهميتها من أن لها مكانة كبرى في أصول التشريع؛ لأنها جمعت الفروع الجزئية المشتَّنة تحت رابط واحد، يسهل الرجوع إليها، وأنه لا مساغ للاجتهاد في مورد النص، هذه القاعدة من القو اعد

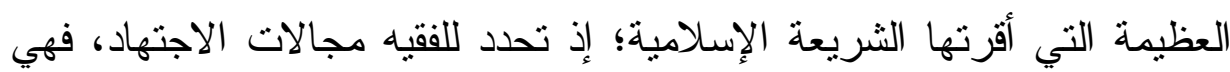
تتص على أن المجتهد لا يجوز لله الاجتهاد في أي قضية شرعية في حال وجود نص قاطع وصريح؛ لأن الحكم الثرعي لتلك القضية حاصل بالنص اليقيني، فليس هنالك حاجة للاجتهاد؛ لأن الاجتهاد لا يكون إلا في ما لا نص فيه، و إنما الاجتهاد في فهم النص ،أو عند خفاء النص وعدم ظهوره؛ فيجب هنا الاجتهاد لفهم النص. 


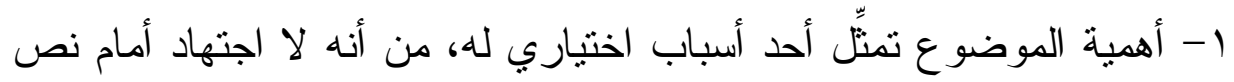

قطعي الثبوت، قطعي الدالة من كتاب الله وسنة نبيه

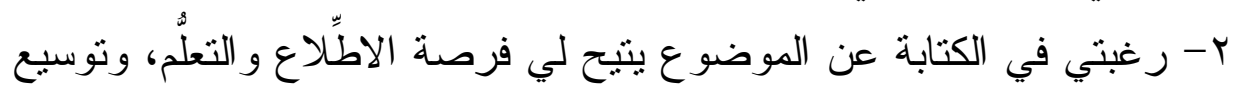

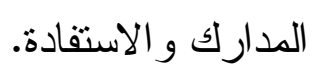
r- الإسهام في إثز اء المكتبة الإسلامية بموضوع مهر، و الذي من شأنه أن يقدم خدمة جليلة للباحثين و الطلاب و المتخصصين. ع - عدم وجود در اسة سابقة تتاولت جميع مسائل هذه الدر اسة.

$$
\text { صعوبات الار اسة: }
$$

1- تشتُّت الموضوع في مجالات عديدة من أركان الإسلام، مثل: فرضية الصلاة، و الزكاة، و المو اريث، و والديات.... إلخ.

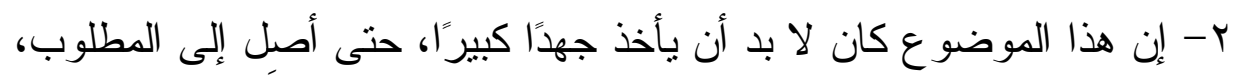
ما أمكنني هذا. وكم يعلم ربي الجهد و الوقت الذي بذلته في هذا الموضو ع. الار اسات السابقة: - العم ربي

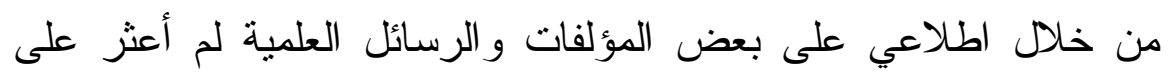

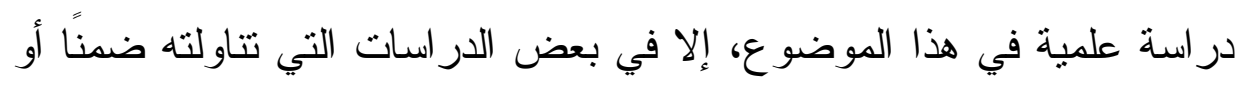

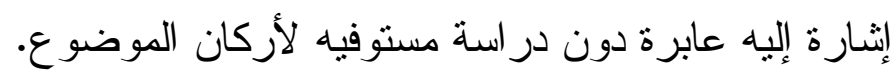
منهج البحث: لقد اعتمدت في هذا البحث على المناهج الآتية: أولاً: المنهج التاريخي. جمعت ما ذكره أهل العلم من المصادر الحديثة، وما ذكره العلماء في الأحكام الفقهية، و التسلسل التاريخي للأحداث وتسجيلها؛ و الوقائع التي حدثت في 


\section{د · نور علي محمود أحمد بـ}

الماضي؛ وتحليلها على أسس علمية؛ بقصد التوصل إلى الحقائق التي تساعدنا في فهم الحاضر على ضوء الماضي. ثانيًا: المنهج الاستقر ائي:

بينت ما ورد في البحث من الآيات القر آنية فعزوته إلى السور التي وردت فيها مع ذكر رقم الآية، واسم السورة، وما ورد من الأحاديث النبوية خرجته

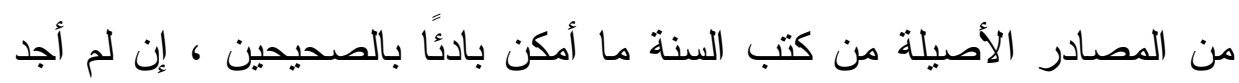

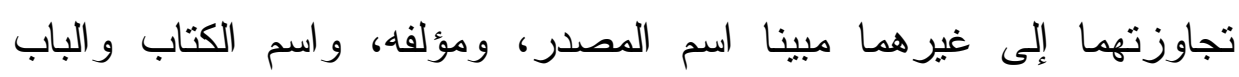
و الجزء و الصفحة، ورقم الحديث إن وجد، و اعتمدت في هذا البحث على مر اجع متتو عة، منها ما يتصل بالمر اجع الحديثة و القديمة. ثالثًا: المنهج النقدي: مانها:

اعتمدت في هذا البحث على ذكر صورة المسألة، والأقو ال الواردة فيها؛

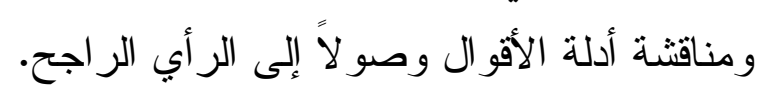

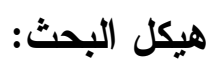

اقتضت طبيعة البحث أن يتكون من مقدمة وثلاثة فصول وخاتمة، وثلاثة فصول، وهذا على النحو التالي: مقدمة: وفيها بيان أهمية الموضوع و أسباب

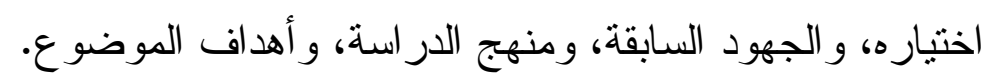
الفصل الأول: لا اجتهاد في مورد النص ، المبحث الأول: تطبيقات فقهية على قاعدة لا اجتهاد في مورد النص، المبحث الثاني: تغير الأحكام الاجتهادية بتغير الزمان، المطلب الأول: تطبيقات فقهية على جواز تغير الأحكام الاجتهادية بتغير الزمان، المطلب الثاني: نقض الاجتهاد بالأدلة الثرعية و النص الظاهر، المطلب الثالث: نقض الاجتهاد بالنص الظني الثبوت، الفصل الثاني: فريضة الصلاة قطعية الثبوت و الدلالة، المبحث الأول: الاجتهاد في تحديد القبلة، المبحث الثاني: الاجتهاد في فقه الزكاة، المبحث الثالث: لا مجال للاجتهاد في القطعيات، المبحث الرابع: قواعد ترنيب الأدلة الثرعية، المطلب 
الأول: تصرف الحكام على الرعية هنوط بالمصلحة العامة، المطلب الثانى :

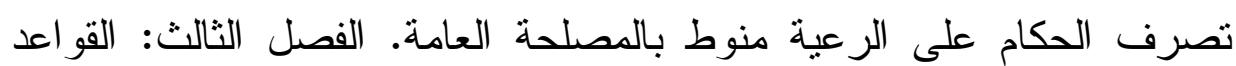

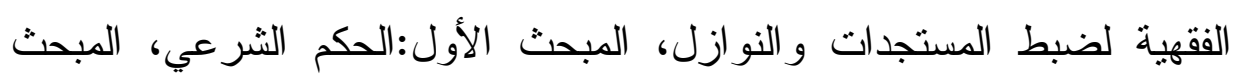
الثاني: أقسام الحكم الثرعي، المبحث الثالث: العلاقة بين الحكم التكليفي و الحكم الوضعي، المبحث الر ابع : الحكم الوضعي. 
د. نور علي محمود أحمد بـ

الفصل الأول: لا اجتهاد في مورد النص(')

هذه القاعدة من القو اعد العظيمة التي أقرتها الثريعة الإسلامية؛ إذ تحدد للفقيه مجالات الاجتهاد، فهي تتص على أن المجته لا يجوز له الاجتهاد في أي قضية شرعية في حال وجود نص فاطع وصريح؛ لأن الحكم الثرعي لتلك القضية حاصل بالنص اليقيني، فليس هناك حاجة للاجتهاد؛ لأن الاجتهاد لا يكون إلا فيما لا نص فيه، أو عند خفاء النص وعدم ظهوره، فيجب هنا الاجتهاد لفهم النص (r). أدلة القاعدة:

وردت أدلة عديدة من الكتاب و السنة والإجماع، تتص على هذه القاعدة، ومن هذه الأدلة ما يلي:

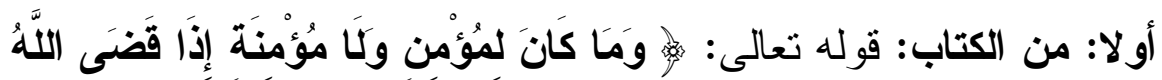

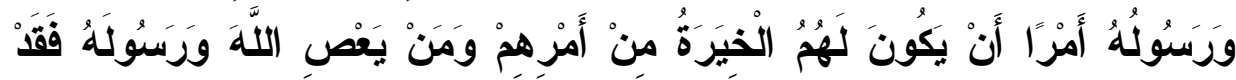

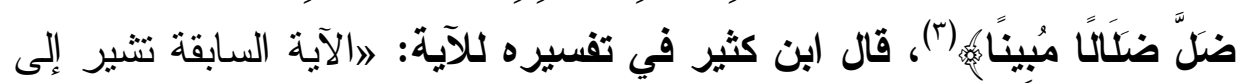
عدم مخالفة حكم الله ورسوله في أي أمر من الأمور، فلا مجال للرأي و الاجتهاد فيما نزل فيه نصه (؟).

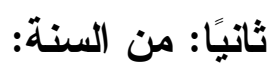
ما روى عن ابن عباس رضي الله عنهما: 》أن هلال بن أمية، قذف امر أته

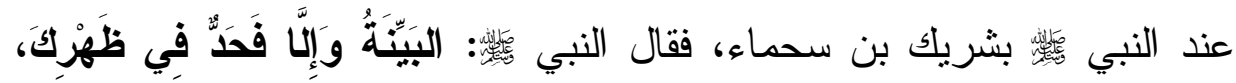
فقال: يا رسول الله، إذا رأى أحدنا رجلًا على امر أته، يلتمس البينة؟ فجعل النبي

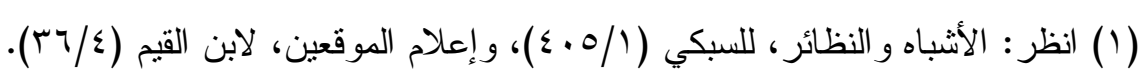

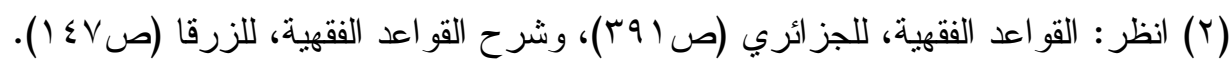
(צ) (Y) سورة الأحزاب الآية (Tr). 


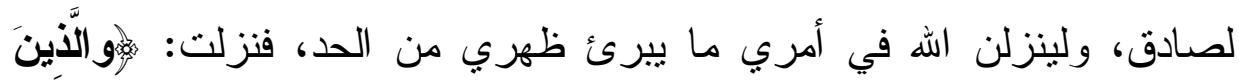

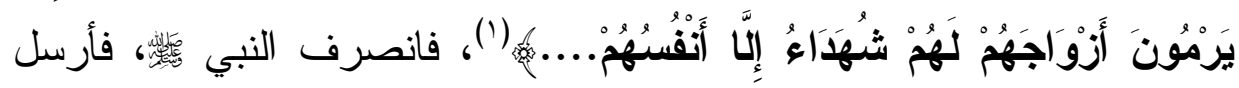

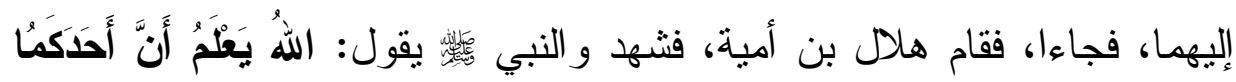

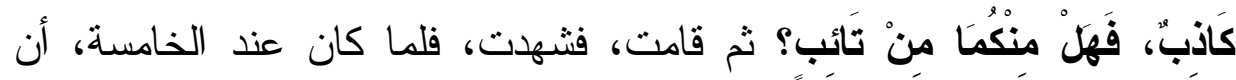

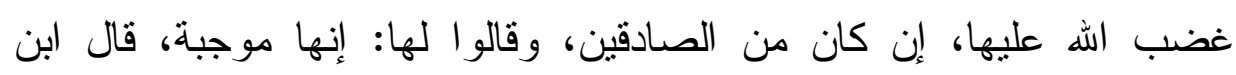

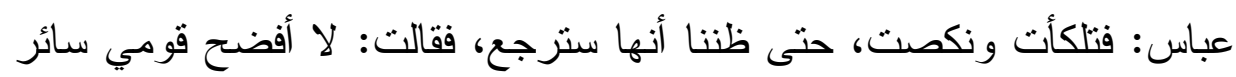

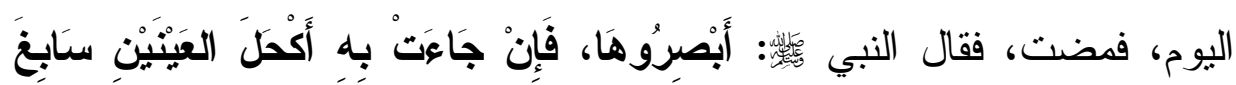

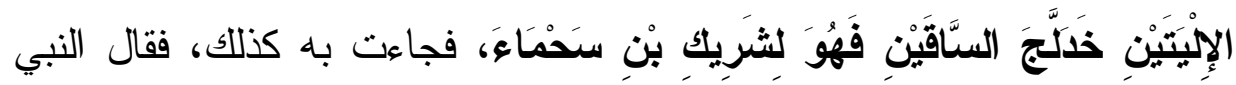

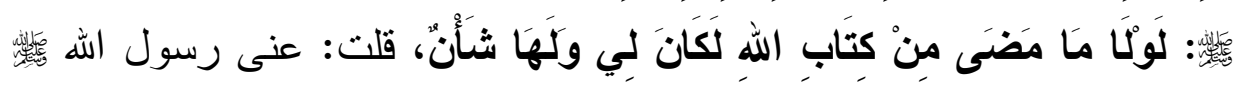

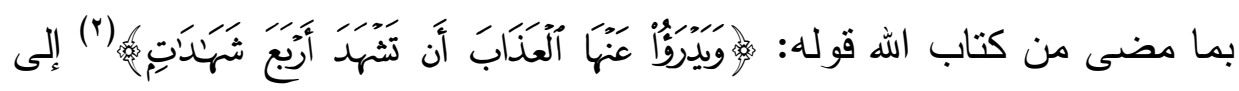

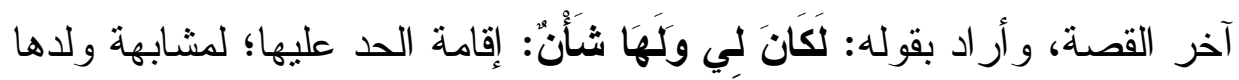
الرجل الذي رميت به، و الهه أعلمه" (r).

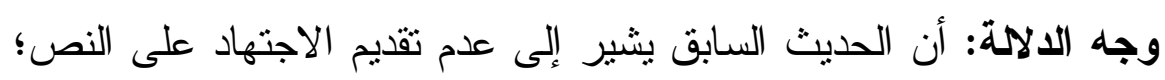

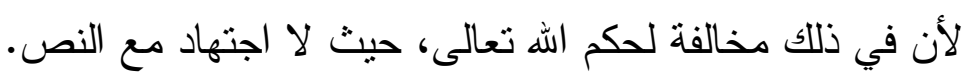

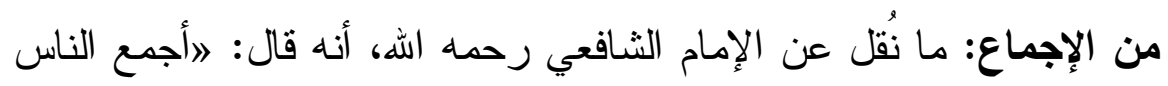

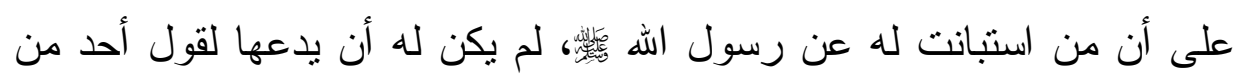

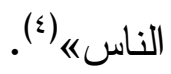

$$
\begin{aligned}
& \text { (1) (1) سورة النور، الآية (7). }
\end{aligned}
$$

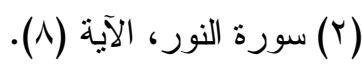

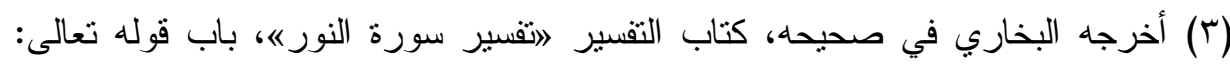

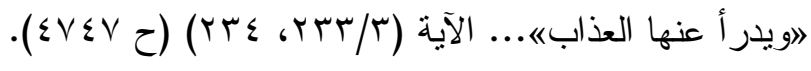

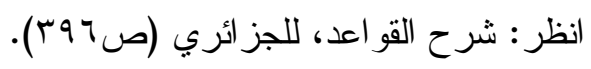

$$
\begin{aligned}
& -1 Y \cdot-
\end{aligned}
$$




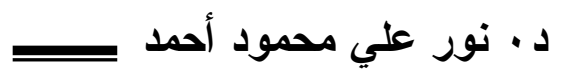

وكذلك قوله: اإذا رويت عن رسول الله حديثًا، ولم آخذ به؛ فاعلموا أن

عقلي قد ذهب" (')

* المبحث الأول: تطبيقات فقهية على قاعدة لا اجتهاد في موارد النص.

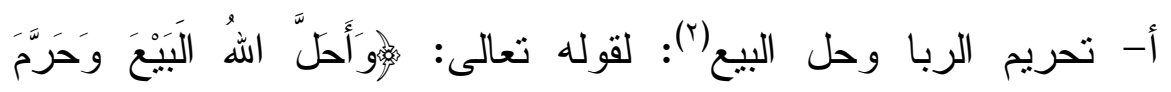

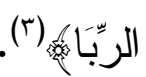

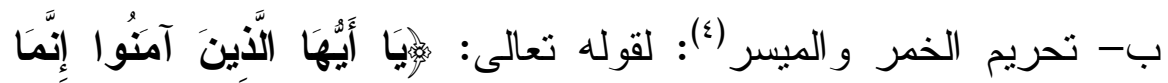

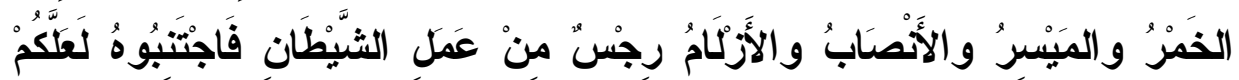

تُقْلحُونَ

وجه الصلة: هذه القاعدة مرتبطة ارتباطًا بقاعدة 》الاجتهاد لا يُنقض العض

بالاجتهاده ومكملة لها، فكما أسلفنا فإن هذه القاعدة تحدد للفقيه مجالات الاجتهاد، فإذا وُجد النص الصريح و القاطع من الكتاب و السنة وغيره من الأدلة الأخرى، فإن الاجتهاد في هذا المقام يكون باطلًا، ويُنقض الحكم المبني عليه، أما إذا كان النص ظنيًا وخفيًا، فإن الحاجة للاجتهاد هنا تكون مُلِحَّة؛ لفهم النص، وتحديد المعنى المر اد منهی)(").

* المبحث الثاني: تغيُّر الأحكام الاجتهادية بتغير الزمان (v).

أي: أن الأحكام الاجتهادية التي تجري في الواقع تتغير بتغير الظروف

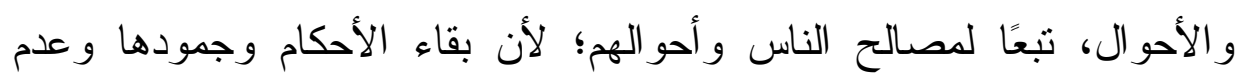

(1) (1) إعلام الموقعين، لابن القيم (ع/ • ع).

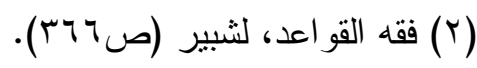

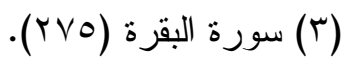

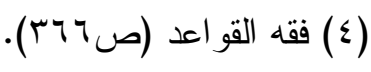

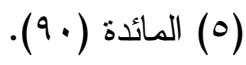

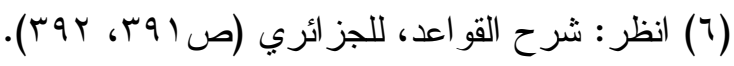

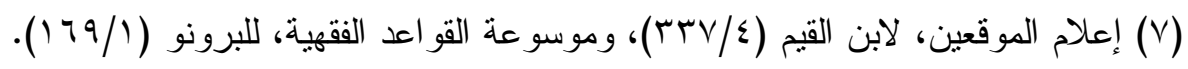




\section{تطبيقات فقهية}

تغيرّها مع تغيُر الزمان و المكان يوقع الناس في حرج ومشقة، وهذا ينافي

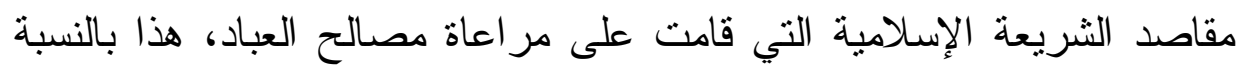

$$
\text { لمأحكام الاجتهادية. }
$$

أما الأحكام الأساسية المقررة بصريح النصوص الثرعية، فلا تقبل التبديل

$$
\text { و التغيير ، مهما تبدل الزمان و المكان ('). }
$$

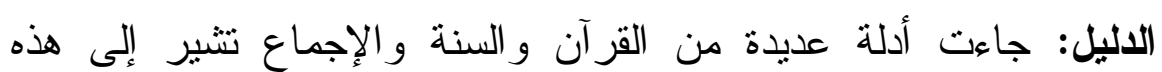

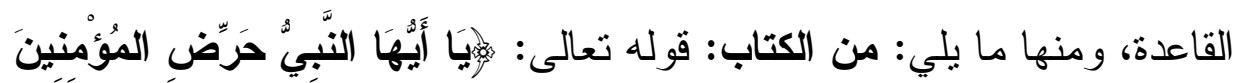

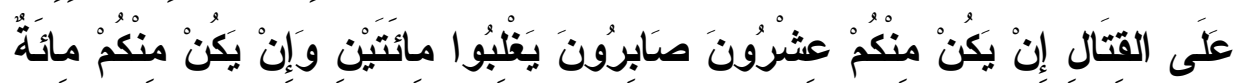

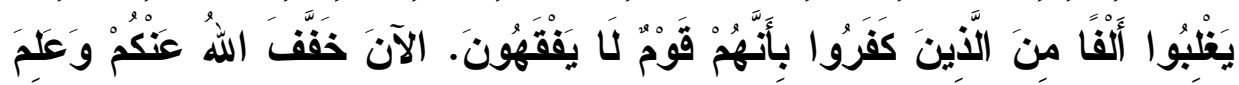

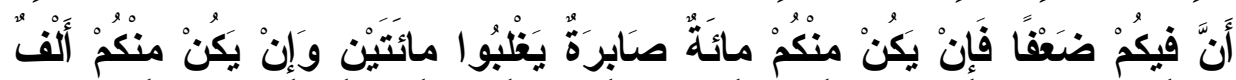

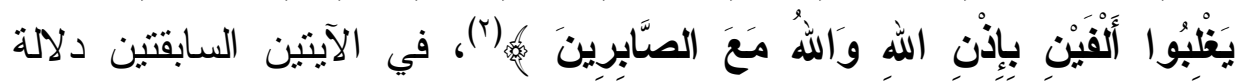

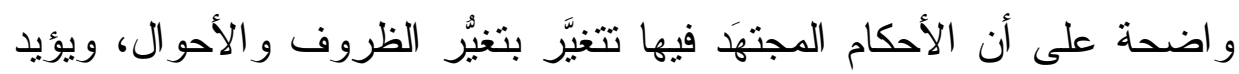

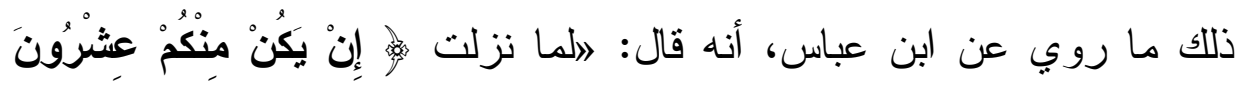

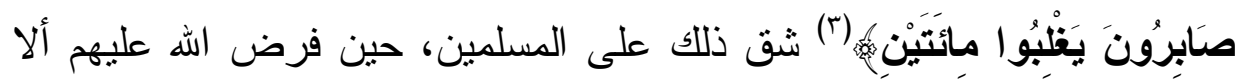

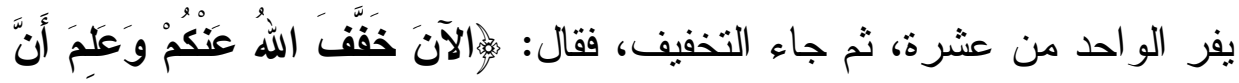

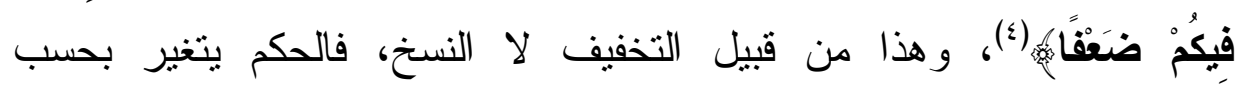

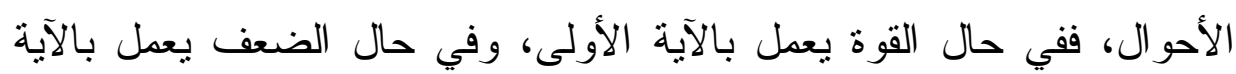

الثانيةه (0).

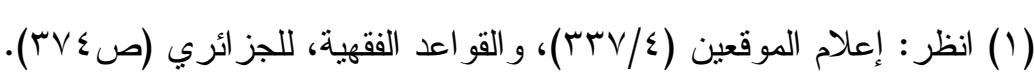

$$
\begin{aligned}
& \text { (T) سورة الأنفال الآيتان (T)، (T)، (T). } \\
& \text { (Y) سورة الأنفال، الآية (T) (T). } \\
& \text { (ك) سورة الأنفال، الآية (TT). }
\end{aligned}
$$

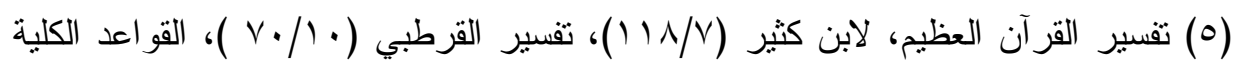




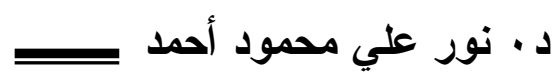

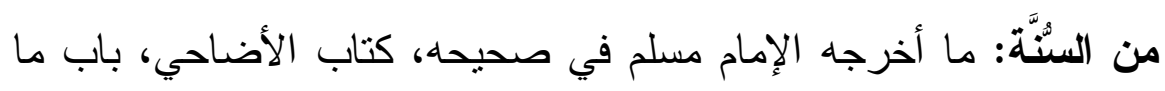

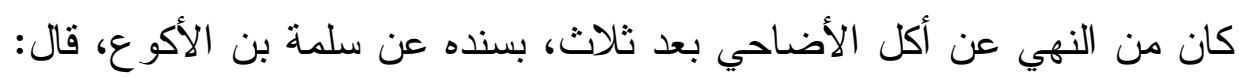

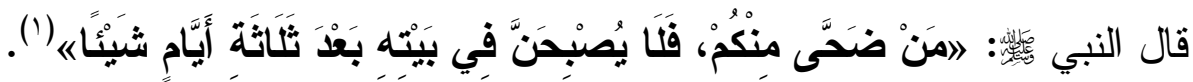
فقد منع النبي

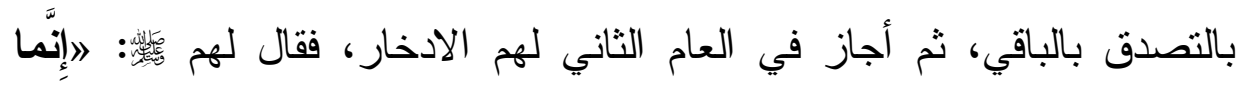

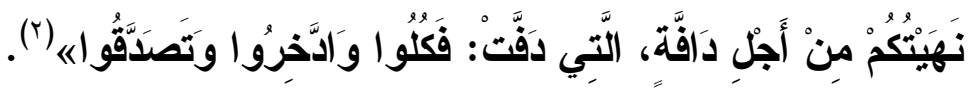
الإجماع: أجمع العلماء على أن الأحكام تتغير بتغيرُ الظروف والمصالح

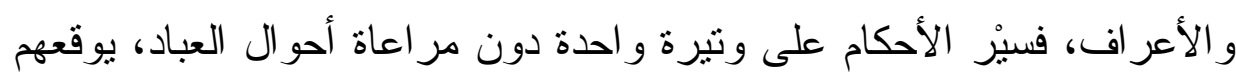

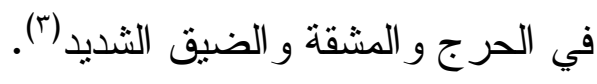

المطلب الأول: تطبيقات فقهية على جواز تغيير الأحكام الاجتهادية بتغير الزمان. أ- أجاز العلماء قبول شهادة الأمتل فالأمتل، و الأقل فجورًا فالأقل، عندما غابت العدالة عن كثثر من الناس في هذا الزمان؛ وذللك حتى لا تضيع الدئ الدصالح وتُهُر الحقوق.

ب- إقرار العلماء بجواز استحداث أحكام سياسية؛ لترهيب وردع أصحاب

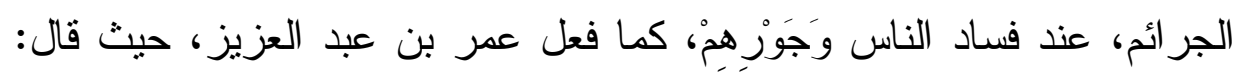

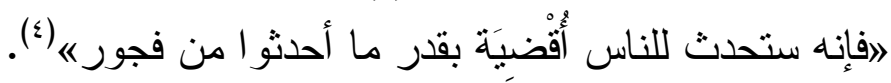

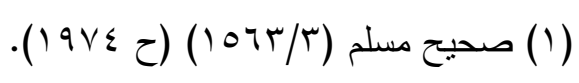

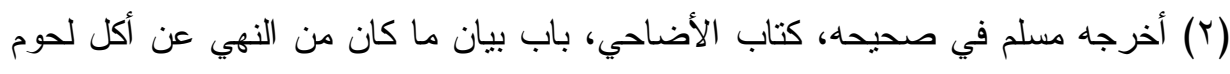

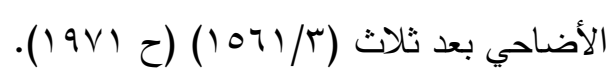

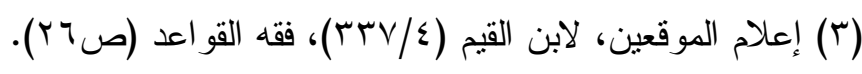

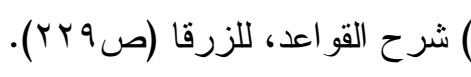




\section{تطبيقات فقهية}

المطلب الثثاني: نقض الاجتهاد بالأدلة الثرعية والنص الظاهر ـ

أولًا: نقض الاجتهاد بالنص القطعي.

صورة المسألة:

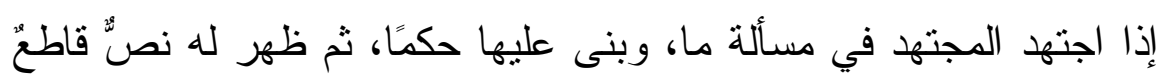

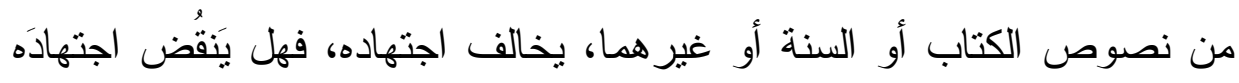

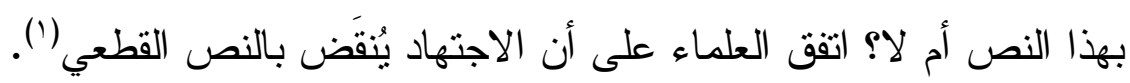

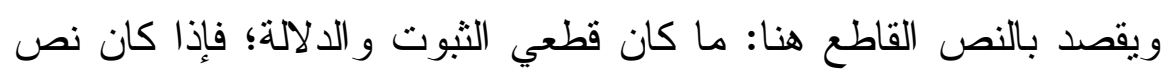

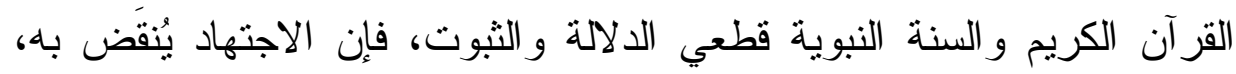

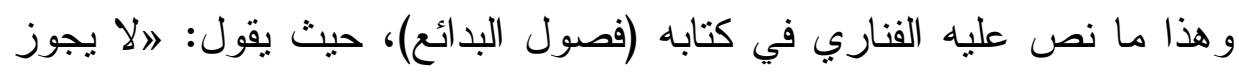
للمجتهد نقض ما حكم به لنفسه؛ لتغير اجتهاده أو غيره لمخالفته اجتهاده اتفاقًا؛

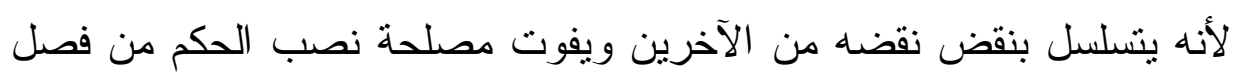

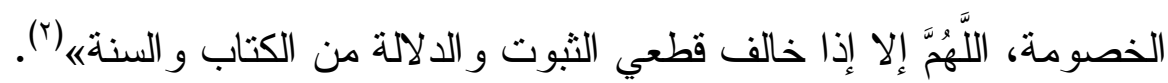

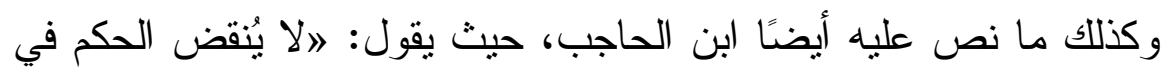

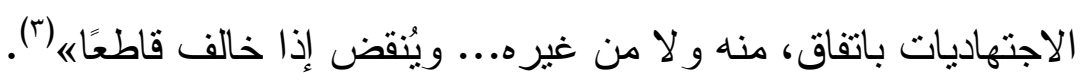

ثانيًا: نقض الاجتهاد بالنص الظاهر: صوة المسألة: إذا اجتهد المجتهد في مسألة ما، وبنى عليها حكمًا، ثم تبين

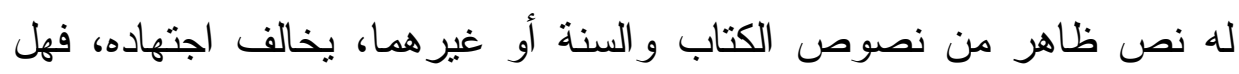

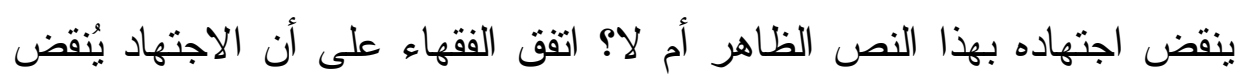

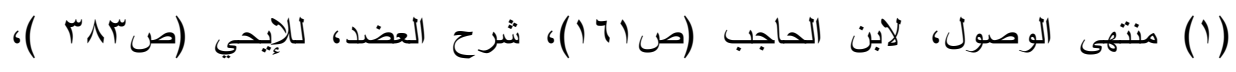

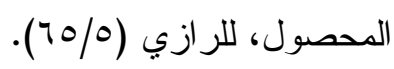

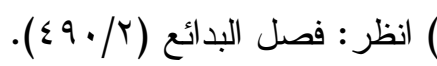

$$
\begin{aligned}
& \text { (r) منتهى الوصل، لابن الحاجب (ص (1) (1)، وشرح العضد، للإيجي (صr/r). } \\
& -1 \text { r } \varepsilon-
\end{aligned}
$$


د. نور علي محمود أحمد بـ

بالنص الظاهر غير الجلي"') و اختلفوا في نقض الاجتهاد بالنص الظاهر

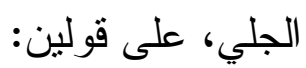

القول الأول: النص الظاهر لا ينقض به الاجتهاد، وبه قال الرازي(؟)، و البغدادي، حيث يقول: (فما كان دليله مقطوعًا عليه، علمنا إصابته، وقطعنا بخطأ من خالفناه، ونقضنا حكمهی(") وبالمفهوم المخالف أنه لا يُنقض بالدليل الظني. القول الثاني: النص الظاهر الجلي يُنقض به الاجتهاد، وبه قال

$$
\text { الزركثي (£) و السبكي. }
$$

سبب الخلاف اختلافهم هل يلحق النص الظاهر الجلي بالدليل القاطع أم لا؟ فمن قال: إن النص الظاهر الجلي يلحق بالدليل القاطع، قال بنقض الاجتهاد بالنص الظاهر، ومن قال: إن النص الظاهر الجلي يلحق بالدليل الظني قال بعدم

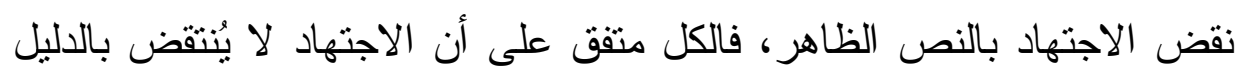
الظني، ويُنتضض بالدليل القطعي، و الخلاف في المفاهيم و المصطلحات. دليل القول الأول: استدل القائلون بعدم نقض الاجتهاد بالنص الظاهر، بما

النص وإن كان ظاهرًا، فإن دلالته ظنية، ولا يُنقض الظني بالظني،

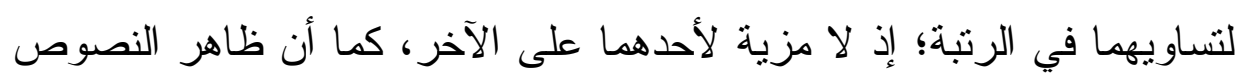
تختلف آر اء المجتهدين فيها، و الاجتهاد لا ينقض بالاجتهاد (0).

$$
\begin{aligned}
& \text { (1) انظر : شرح العضد (صrیr)، و المحصول، للر ازي (T/7). }
\end{aligned}
$$

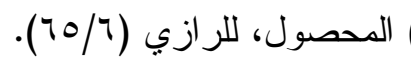

$$
\begin{aligned}
& \text { العدة، للبغدادي (1079/0) }
\end{aligned}
$$

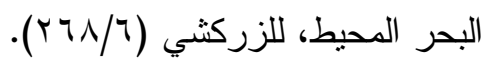

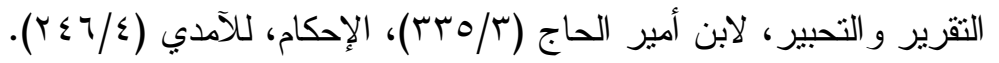


دليل القول الثاني: استدل القائلون بنقض الاجتهاد بالنص الظاهر بما يلي: لإنه

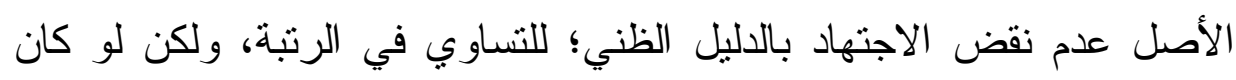

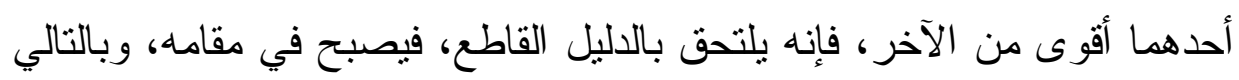

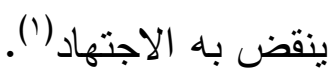

\section{الراجح:}

من خلال ما سبق: فإنني أرجح القول بنقض الاجتهاد بالنص الظاهر

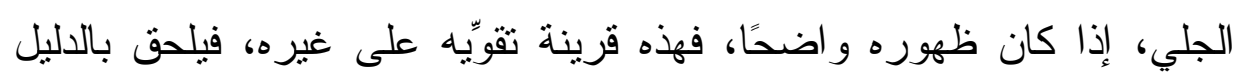

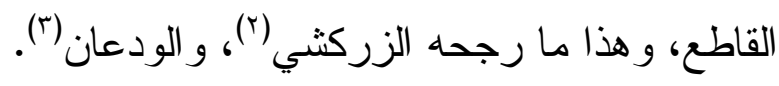
المطلب الثالث : نقض الاجتهاد بالنص الظني الثبوت.

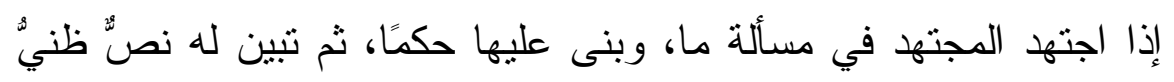

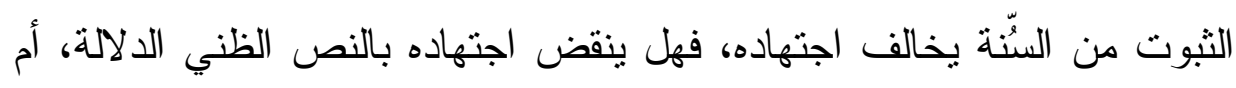

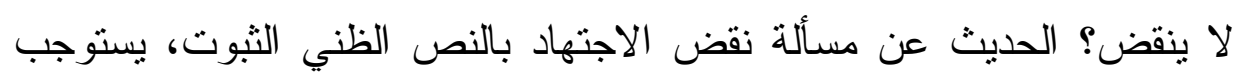

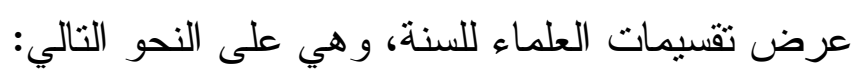

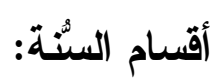

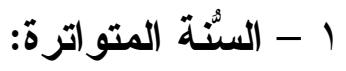

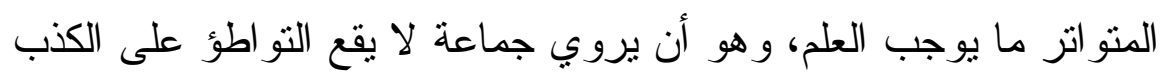

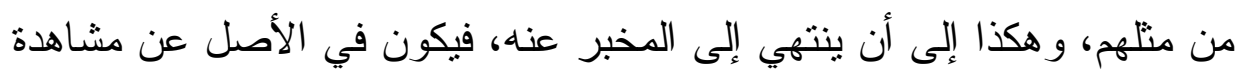
أو سماع، لا عن اجتهاد (\{).

$$
\begin{aligned}
& \text { (1) (1) نقض الاجتهاد، للودعان (ص0). }
\end{aligned}
$$

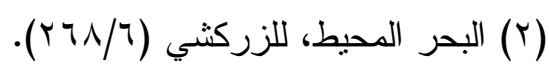

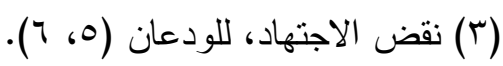

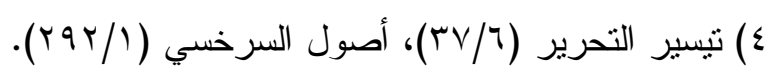

$$
\begin{aligned}
& -1 \text { rY- }
\end{aligned}
$$


د. نور علي محمود أحمد بـ

حكم نقض الاجتهاد بالسنة المتواترة:

كما هو معلوم عند جمهور الأصوليين، فإن السنة المتواترة قطعية؛ لإفادتها العلم الضروري، وما دامت السنة المتواترة قطعية فإن الاجتهاد يُنضض بها، وقد ألمحت' إلى أن الاجتهاد يُنقض بالنص القطعي، كما هو متفق عليه عند الأصوليين.

يقول ابن أمير الحاج في السئنة: اوينقض إذا خالف قطعيًا منها، ولا

ينقض مخالفته الظني؛ لتساويهما في الرتبةه| (').

r - السنة المشهورة:

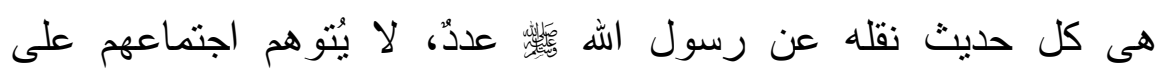

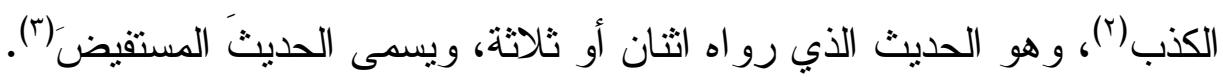

آراء العلماء في السئّة المشهورة ونئ

الكلام عن نقض الاجتهاد بالستُنة المشهورة، يستوجب بيان آر اء العلماء في

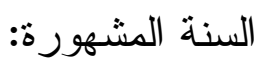

القول الأول: السئنة المشهورة قسيم الخبر المتواتر، وبه قال عامة

الحنفية)(؟).

القول الثاني: السُّنة المشهورة قسم من أقسام خبر الآحاد، ويُنسب هذا

القول إلى جمهور أهل العلم (0).

القول الثالث: السيُّة المشهورة في درجة بين المتواتر و الآحاد، فهي أعلى رنبة من خبر الآحاد، و أقل رنبة من الخبر المتواتر، فهي توجب علم الطمأنينة

لا علم اليقين، وبه قال عيسى بن أبان و غالب الحنفية(؟).

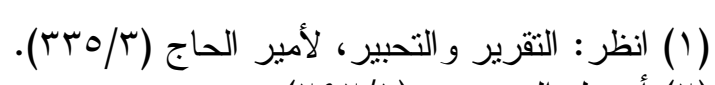

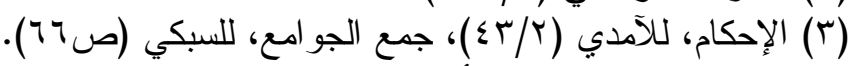

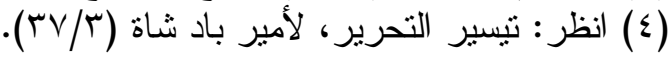

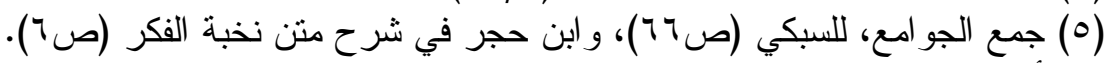

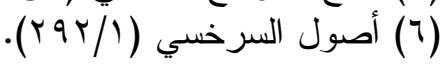


حم نقض الاجتهاد بالسنة المشهورة:

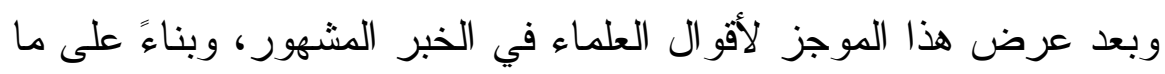

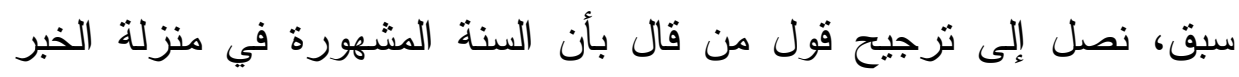

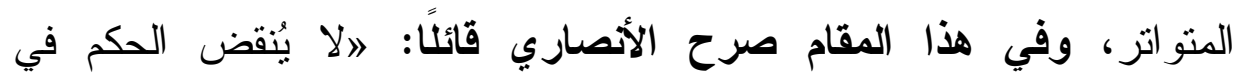

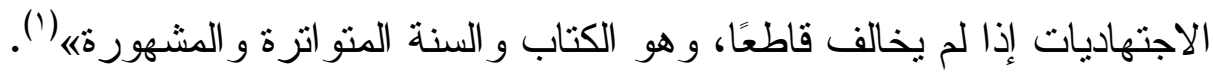

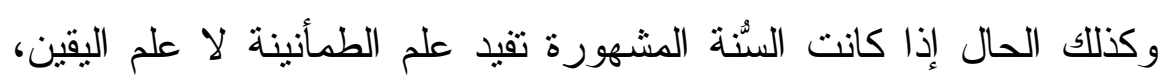

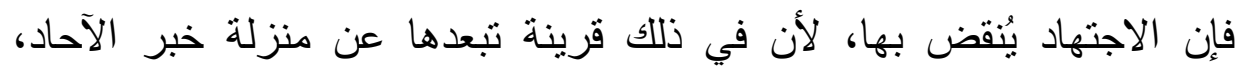

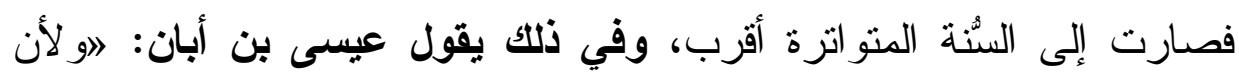

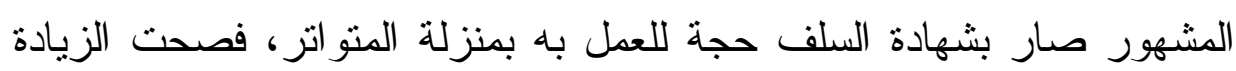

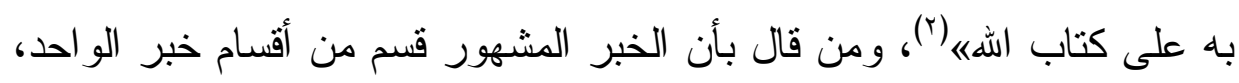
فال بعدم نقض الاجتهاد بالخبر المشهور ؛ لإفادة كليهما الظن (َ).

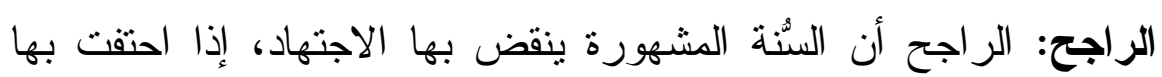
القر ائن التي تفيد العلم، فإنه بذلك أصبح محكومًا بصدقه.

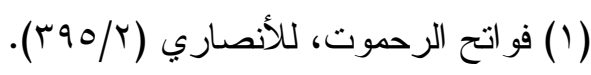

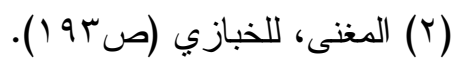

$$
\begin{aligned}
& \text { (r) انظر : العدة، للبغدادي (r) (1079/0). }
\end{aligned}
$$




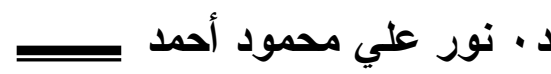

\section{الفصل الثاني: فريضة الصلاة قطعية الثبوت والالاية}

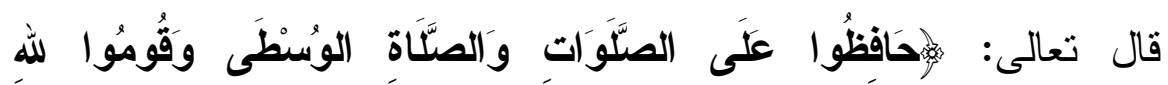

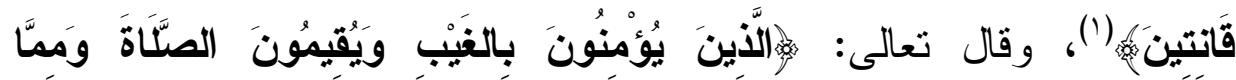

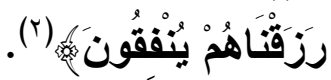

قلث: لقد ورد في القرآن الكريم لفظة (الصلاة) في أكثر من (00) آية قر آنية، فالصلاة هي من أركان الإسلام الخمسة بعد ركن الثهادتين، وفي الصلاة سر عجيب لا يعرفه إلا من أقامها، فهي نور في الوجه، وانشر الح في الصدر، وطمأنينة في النفس، وقوة في القلب، وثبات في الخطى، وتوفيق وتسديد في الأمور، وتيسير في الحياة، وسعة في الرزق، ومحبة من الخلق، وزيادة في الإيمان، وقوة في البدن، وهي شعار العبودية ودليلها، وهي حفظ وستر ، ورفعة، وعزة، وكر امة، وغنى بالله عما سو اه، وهي النجاة من كل شدة

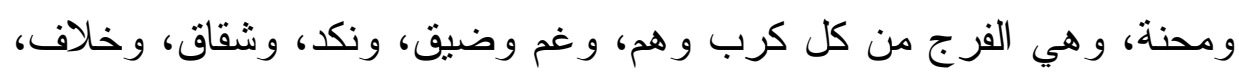

$$
\text { وهي سفينة النجاة. }
$$

وقد ثبتت السنة عن رسول اله هئل

الأوقات على ما عليه عمل أهل الإسلام اليوم، مما تلقوه خلفًا عن سلف، وقرنًا

$$
\text { بعد قرن، كما هو مقرر في موضعده، ولله الحمد (r). }
$$

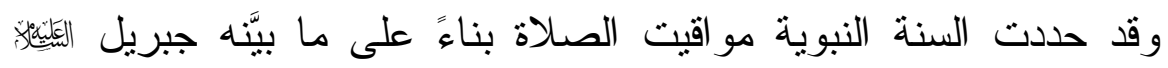

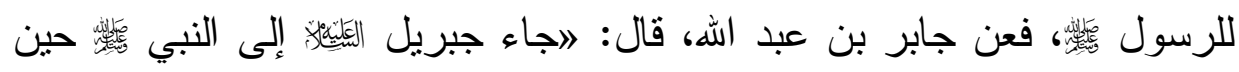
زالت الثمس، فقال: قم يا محمد، فصل الظهر حين مالت الثمس، ثم مكث

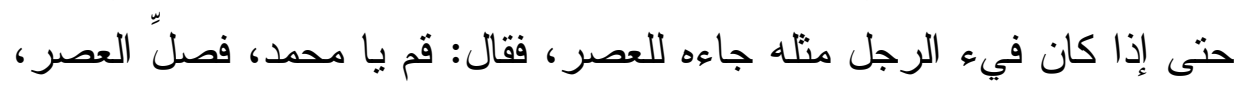

$$
\begin{aligned}
& \text { (1) سورة البقرة، الآية (Yی) (Yr). }
\end{aligned}
$$

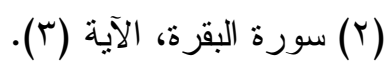

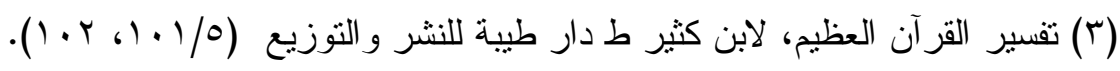


ثم مكث حتى غابت الثمس جاءه، فقال: قم يا محمد فصل المغرب، فقام

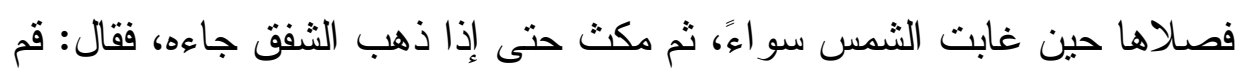

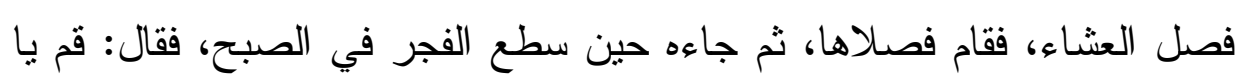
محمد فصل، فقام فصلى الصبح.

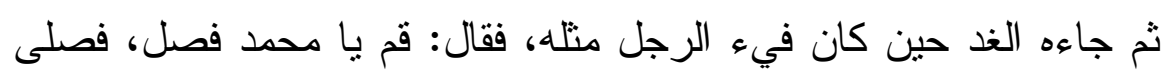

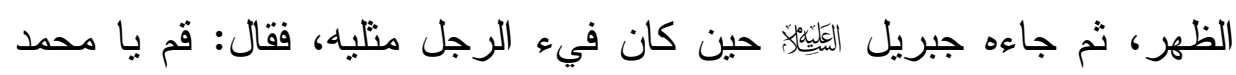

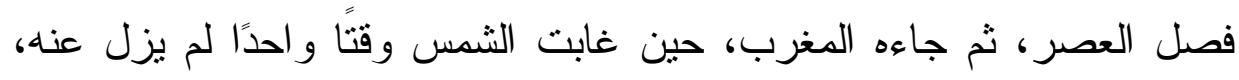
فقال: قم فصل، فصلى المغرب، ثم جاءه للعشاء، حين ذهب نلاءه الث الليل الأول،

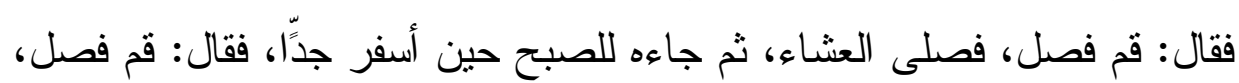

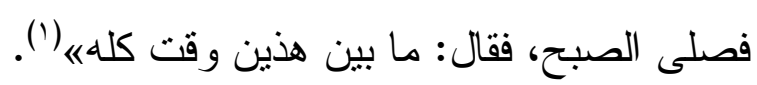

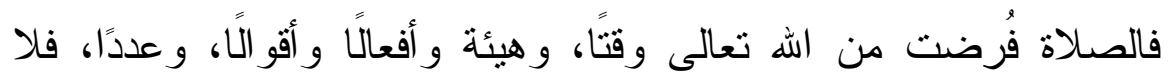

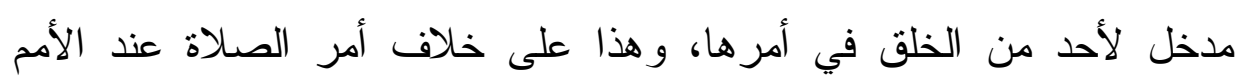
الأخرى. - الاخل

\section{* المبحث الأول: الاجتهاد في تحديد القبلة.}

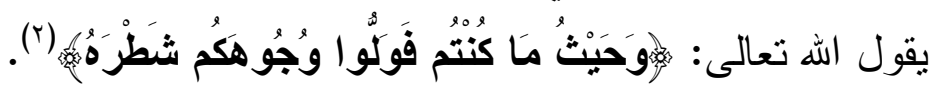

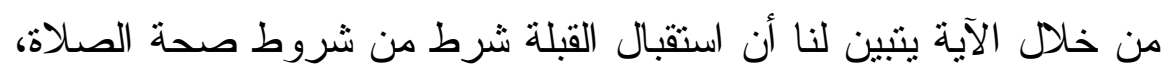

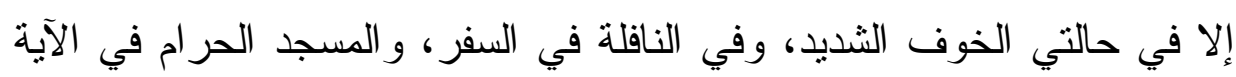

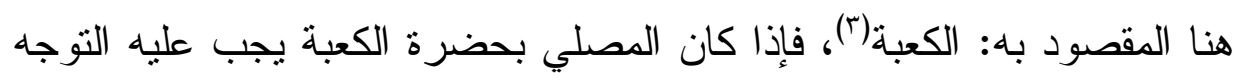

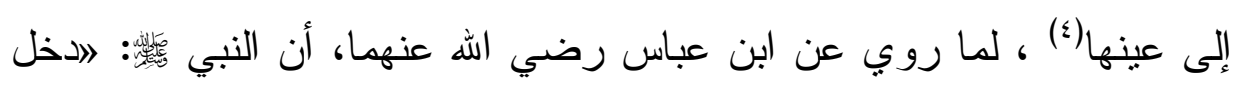

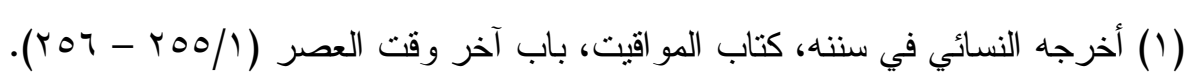

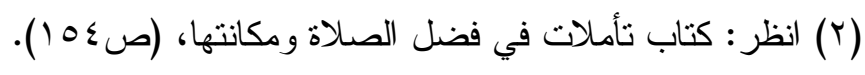

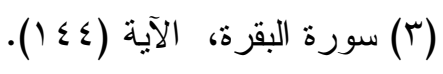

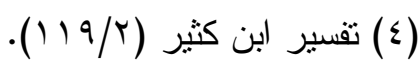


د. نور علي محمود أحمد بـ

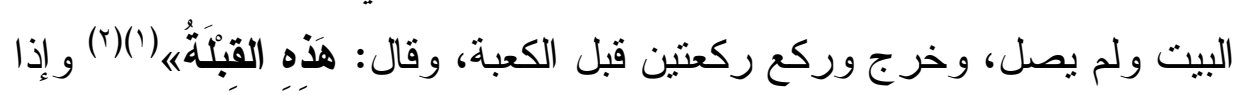

كان المصلي بعيدًا عن الكعبة، اجتهد في تعيين القبلة('). * المبحث الثاني: الاجتهاد في فقه الزكاة:

\section{يقول العلماء: الاجتهاد نوعان:}

اجتهاد في فهم النصوص: لإمكان تطبيقها، وهذا و اجب على كل مجتهد،

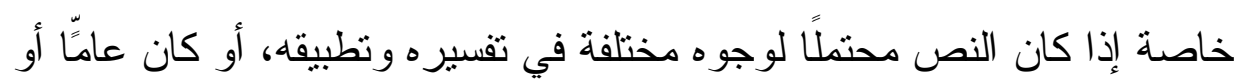
مجمًا أو مطلقًا، و اجتهاد عن طريق القياس و الرأي: وهذا لا يجوز الالتجاء

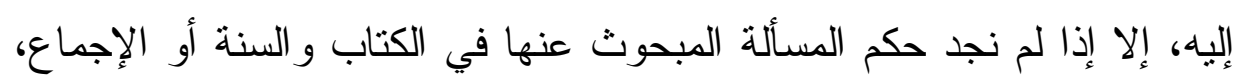

وهو المقصود هنا(£).

فالقياس يكون فاسد الاعتبار ، إذا خالف نصمًا أو إجماعًا، باعتبار أن القياس

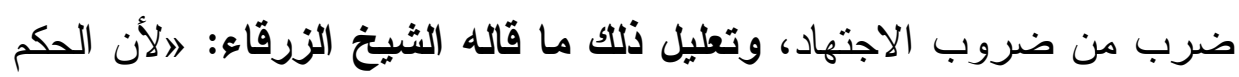
الثرعي حاصل بالنص، فلا حاجة لبذل الوسع في تحصيله، ولأن الاجتهاد ظني، و الحكم الحاصل به حاصل بظني، بخلاف الحاصل بالنص فإنه يقيني، و لا يترك اليقيني للظني"(o)، فلا يمكن بأي حال أن يقول أحد: يمكننا تخطي

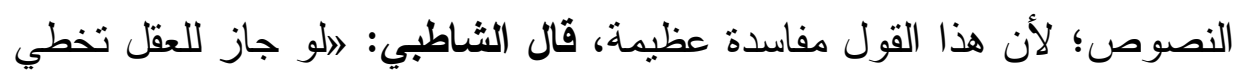
مآخذ النقل، لجاز إبطال الثريعة بالعقل، وهذا محال وباطله(؟)، وقال البيانوني: الو سُّح لكل إنسان أن يجتهد في مقابلة النصوص، لتعطل العمل وهل

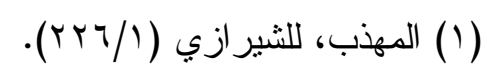

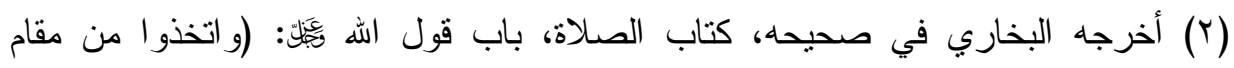

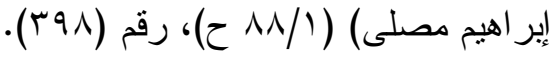

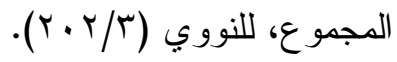

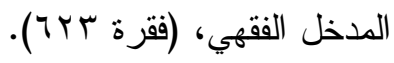

$$
\begin{aligned}
& \text { (0) شرح القو اعد، (صلوحه). }
\end{aligned}
$$

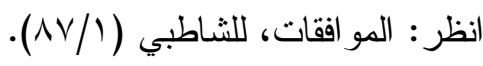


بها، وفقدت النصوص مشروعيتها ومصداقيتها، وضاعت دلالتها بين الناس") (1)، فوضع هذه القاعدة يحفظ الثريعة، ويغلق الباب أمام العقلانيين؛ لئلا

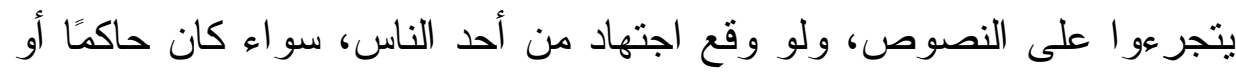

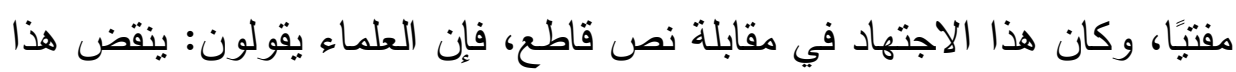

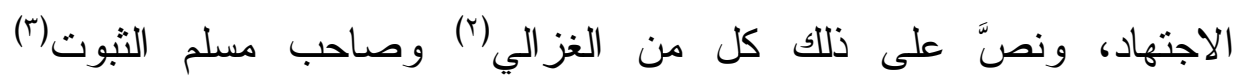

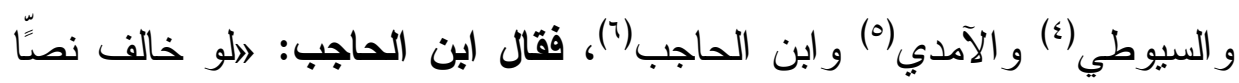

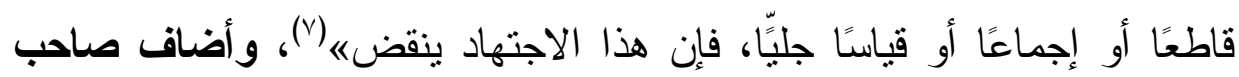

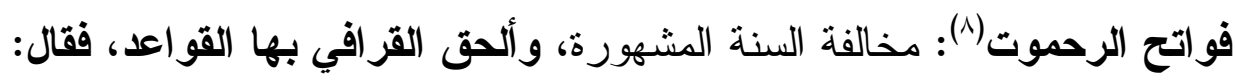
الاو الحكم الذي ينقض في نفسه ولا يمنع النقض، ما خالف أحد أمور أربعة: الإجماع أو القو اعد أو النص و القياس الجليه" (9).

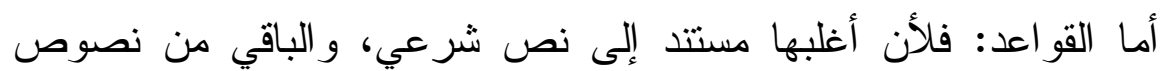

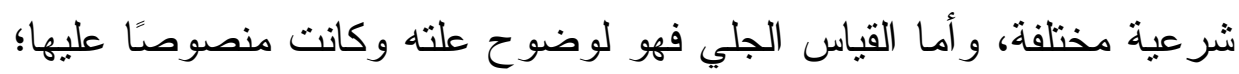

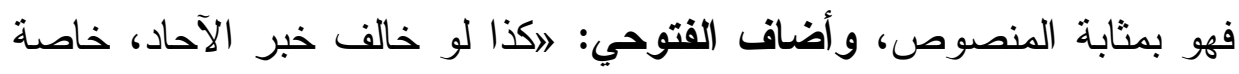

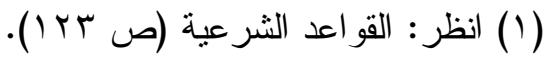

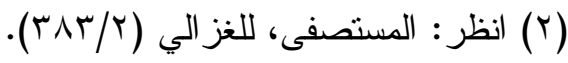

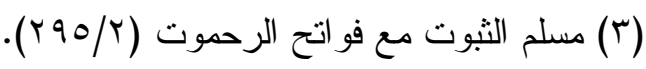

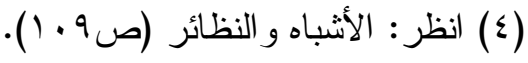

$$
\begin{aligned}
& \text { (1) الإحكام في أصول الأحكام. }
\end{aligned}
$$

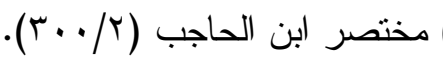

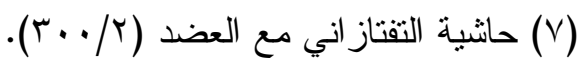

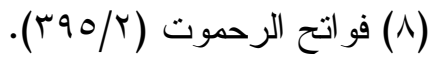

$$
\begin{aligned}
& \text { (9) تنقيح الفصول (ص (1) ـ). }
\end{aligned}
$$




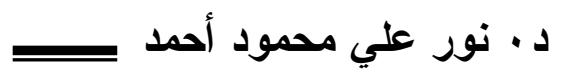

إذا صح سنده واحتقت به قرائن(')؛ وذلك للخروج من خلاف الغزالي في

ذللى (r).

وتوضيحًا لهذه القاعدة في باب الزكاة، نذكر مثالًا، فبالمثال يتضح المقال:

أوضح مثال في ذلك: حولان الحول لإيجاب الزكاة، و المقصود بذلك

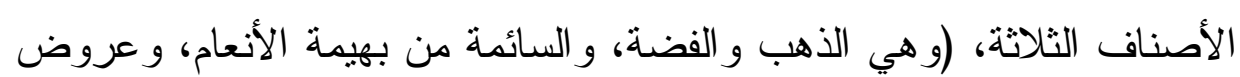

التجارة)، فهذه الثلاثة غير المال المستفاد فيها دليلان و اضحان، أولاهما: الإجماع، ونقل الإجماع كل من ابن قدامة، فقال: أما الثلاثة السائمة و الذهب

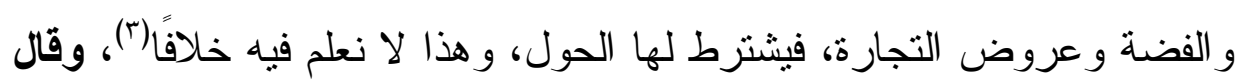
الكاساني: ״لا خلاف في أن أصل النصاب يشترط له الحوله(؛)، وكذا ابن حزم، فقال: 》اتققو العى أن الزكاة تتكرر في مال عند انقضاء كل حول، حاثـا

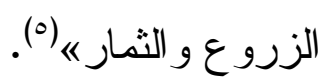

والثاني: ما رو اه من حديث علي رضي الله عنه، قال: قال رسول الله

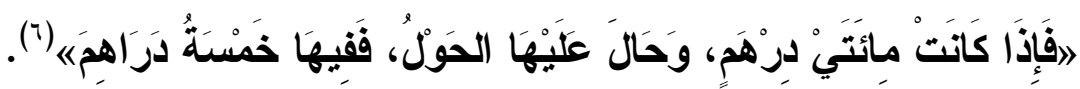

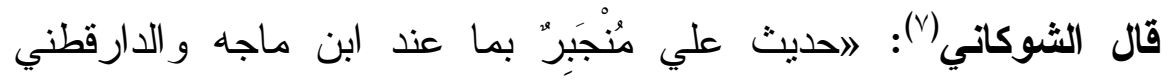
و البيهقي و العقيلي، من حديث عائثة رضي الله عنها ترفعه: (لَّا زكَاةَ فِي مَالٍ

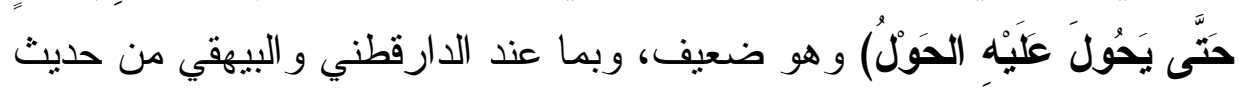

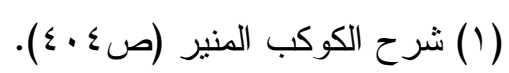

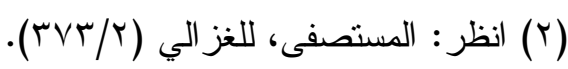

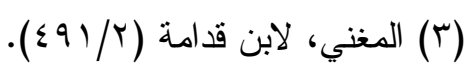

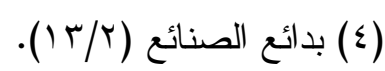

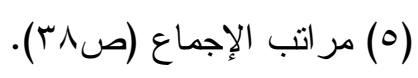

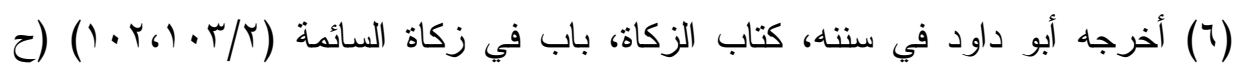




\section{تطيقات فقهية}

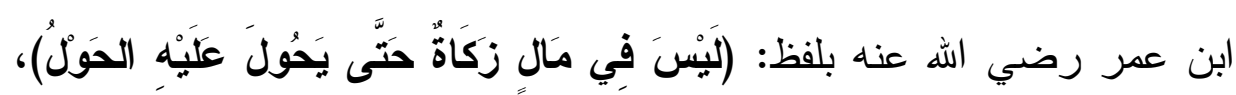

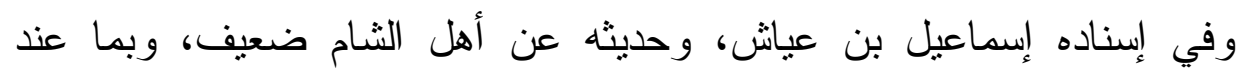
الدارقطني من حديث أنس، وفيه حسان ابن سياه، وهو ضعيف، وحنئه فالحديث له له

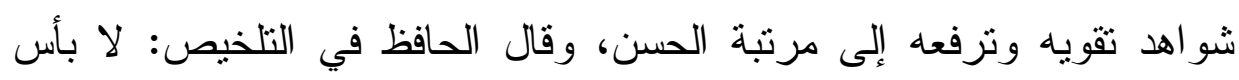

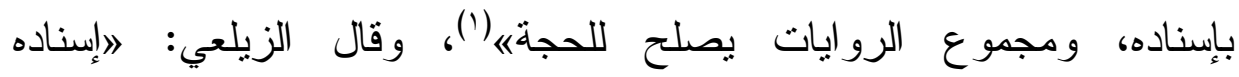

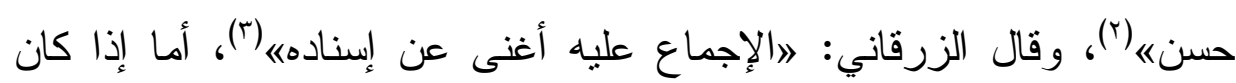

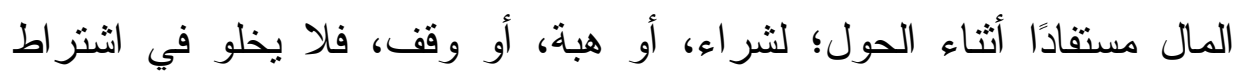

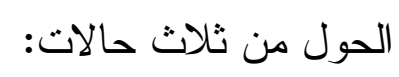

الأولى: إذا كان المال المستفاد من نماء المال، فهذا يشترط له الحول اتفاقًا.

نص عليه ابن قدامة(؛).

والثانية: إذا كان المال المستفاد من غير جنس ما عنده فقيه خلاف. قال

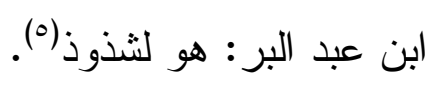

الثالثة: إن كان من جنس نصاب عنده، حال عليه حول الزكاة، سبب

مستقل.

فإن لزم الإجماع في الأولين، لا يمكن الفرار من النص الصحيح الصريح

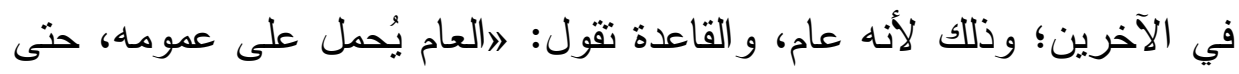

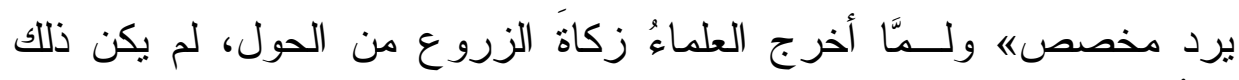

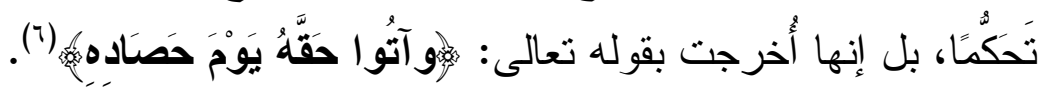

$$
\begin{aligned}
& \text { (1) انظر : تلخيص الحبير (Y/Y) (107). } \\
& \text { (Y) نصب الر اية (Y (YN/Y) }
\end{aligned}
$$

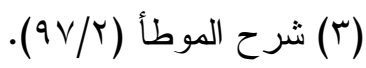

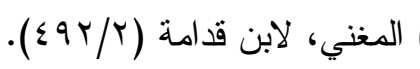

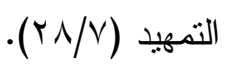

$$
\begin{aligned}
& \text { (T) سورة الأنعام، الآية (إ)(ا). }
\end{aligned}
$$




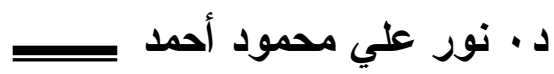

* المبحث الثالث: لا مجال للاجتهاد في القطعيات.

وهذا القيد يخرج أمورًا، اتفقت الأمة وأجمعت سلفًا وخلفًا، أنها لا تقبل الاجتهاد، و لا يمكن لأي إنسان أن يعمل عقله فيها، والمر اد بالقطعيات: الأحكام التي لا تتبدل على مدى الزمان، وهي التي تثبت بدليل نقلي لا شك في ثبوته وفي دلالته، أو ثبت بطريق عقلي لا شك فيه. والقطعيات في الثريعة الإسلامية ما يلي:

ا- العقائد و الغيبيات التي جاءت بها الثريعة، وهذا و اضح باعتبار أنها لا تتغير و لا تتبدل.

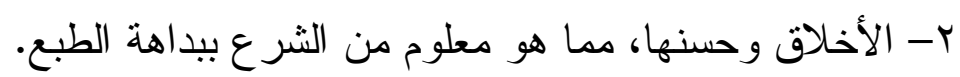

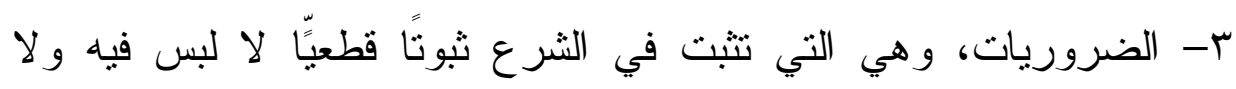

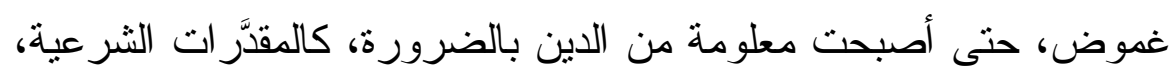
ومن ذلك الحدود.

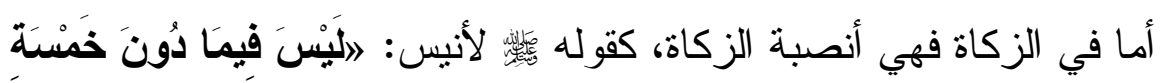

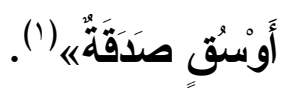

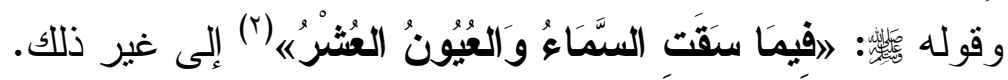
فلا مجال لأي إنسان أن يحاول تغير أنصبة الزكاة، وما يؤخذ منها، وقد فعل ذلك بعض المعاصرين، وقال: »الا بد من مر اجعة أنصبة الزكاة، وما بؤخذ منها لتحقق مقاصد الثريعةه. ع- ومن القطعيات التي لا يجوز فيها الاجتهاد: الأحكام المؤبَّدة، وهي التي نص الثار ع على تأبيد أحكامها كفريضة الجهاد.

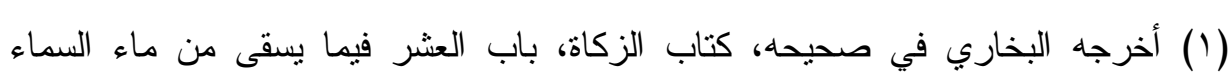

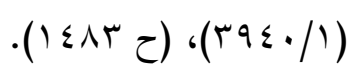

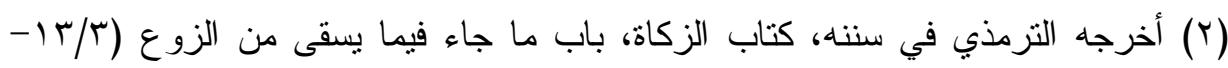

$$
\text { (TrV }(\text { ) })(1 \leq
$$


* المبحث الرابع: قواعد ترتيب الأدلة الثرعية .

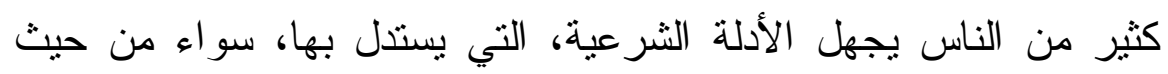

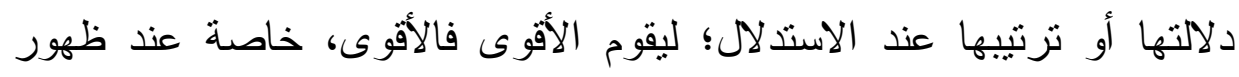

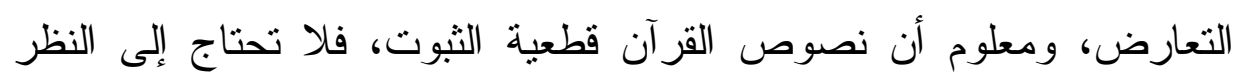
فيها.

أما دلالتها، فتحتاج إلى تثبُت لمعرفة القطعي من الظني، وذلك لوجود

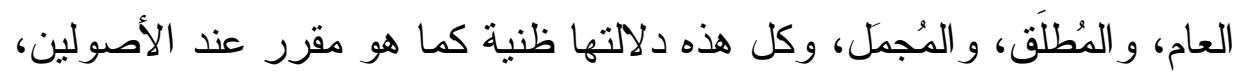

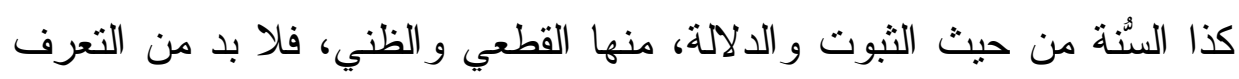

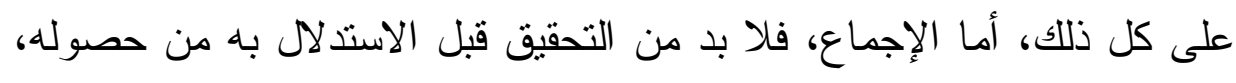

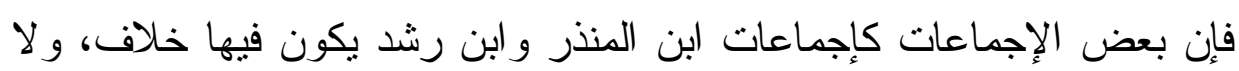

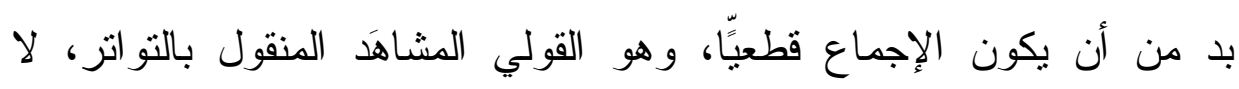
المنقول بالآحاد أو الإجماع السكوني؛ لأنهما ظنيان. و على ما سبق، فلا بد من تقدم الإجماع القطعي، في الدلالة على غيرها. لإنهان.

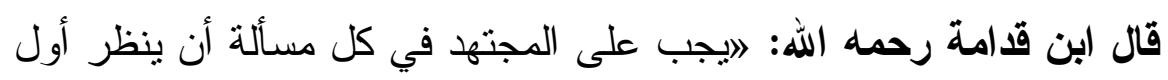

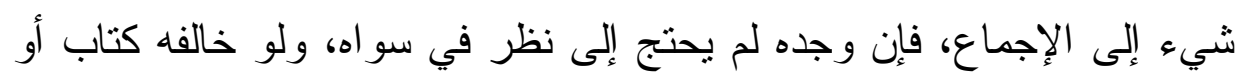

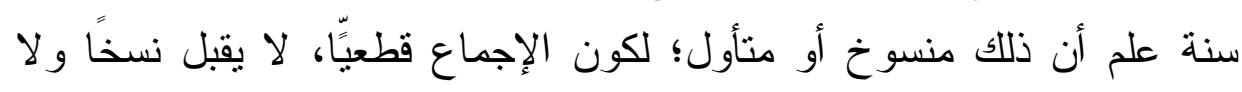
تأويلًاه (')

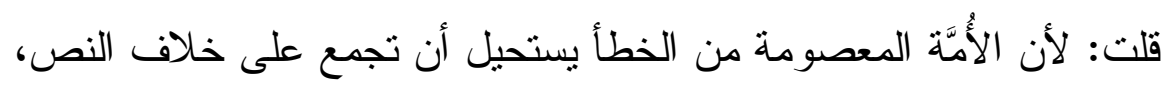

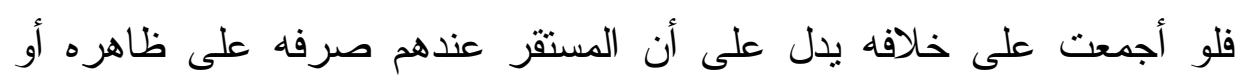




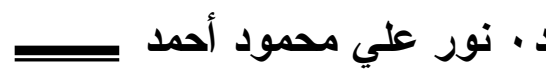

نسخه، وقد يجعل الإجماع الحديث صحيحًا، ولو كان سنده ضعيفًا، كدديث:

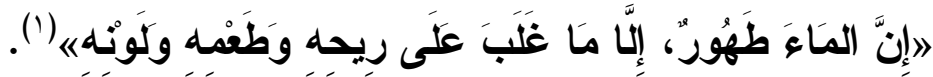

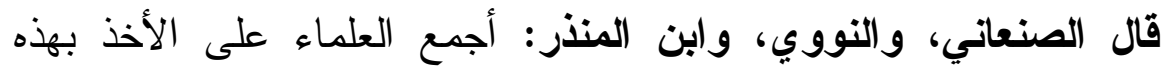

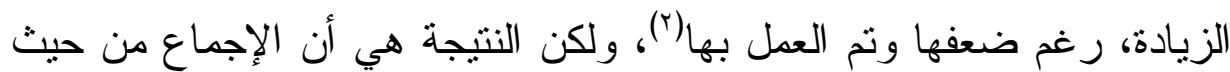

الدلالة أقوى، فينبغي ألا يفرط فيه، وتظهر أهمية الإجماع في موضعين:

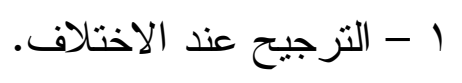

ب - الترجيح عند تعارض الأدلة.

؛ - قواعد خاصة لضبط اجتهاد الإمام في الزكاة:

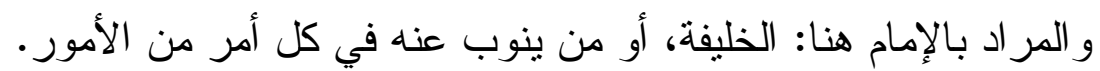

$$
\text { و إليك هذه القواعد في مطالب: }
$$

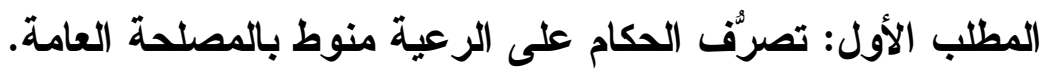

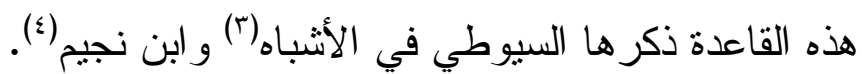

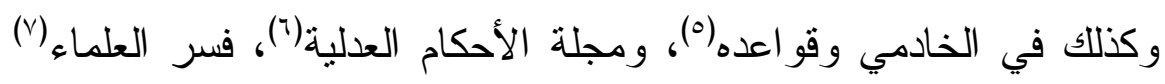

المصلحة المرادة هنا بجلب المنفعة ودفع الدفسدة، وفي القاعدة دلالة واضحة

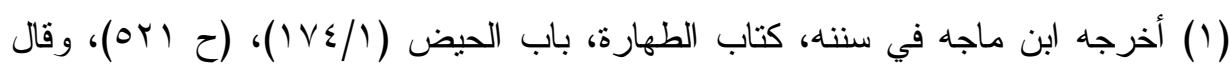

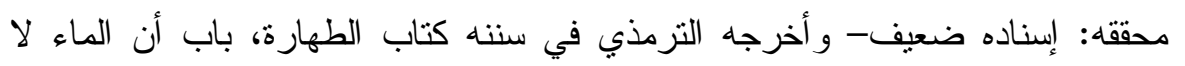

$$
\begin{aligned}
& \text { ينجسه شيء (10/1 ح ح 77) وحسنه الترمذي. }
\end{aligned}
$$

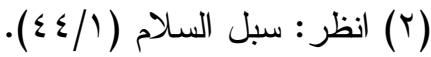

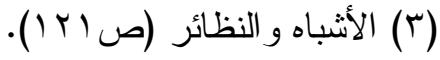

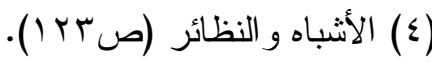

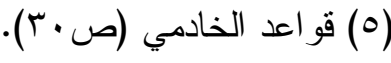

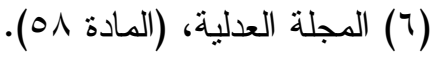

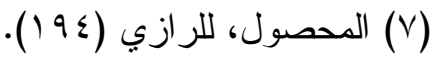


على أن الإمام يتصرف في رغيته، بما يجلب لها المنفعة، ويدفع عنها المفسدة؛ لأن الثريعة دعت إلى ذلك.

قال الثاطبي: "إن الأحكام الثرعية ليست مقصورة لذاتها، و إنما قُصد بها

$$
\text { أمور أخرى، هي: معانيها و المصالح التي شرعت لألجام لألهاه ('). }
$$

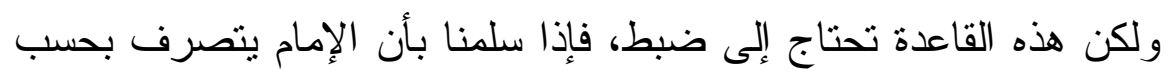

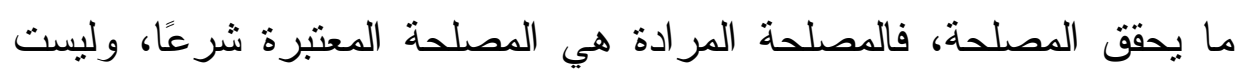

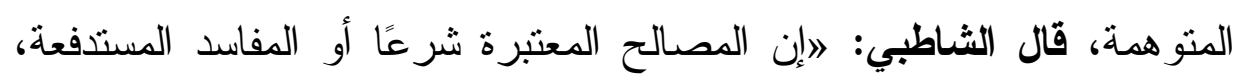

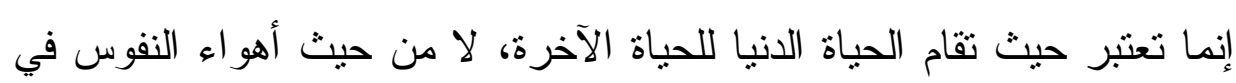

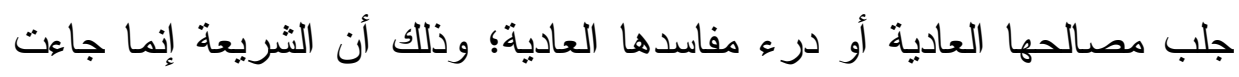

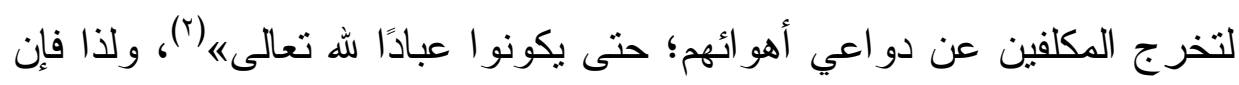

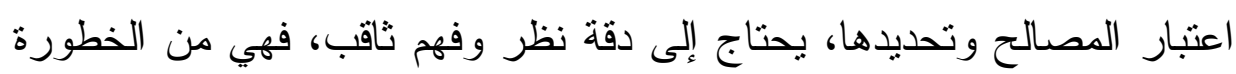

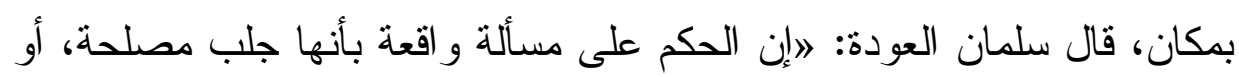
در ء مفسدة يحتاج إلى يقظة وتحرِّ وفهم و إدر الكه (َ).

\section{وتتعاظم خطورة تحديد المصلحة بالنظر إلى ما يلي:}

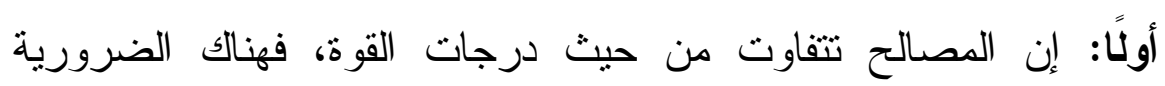

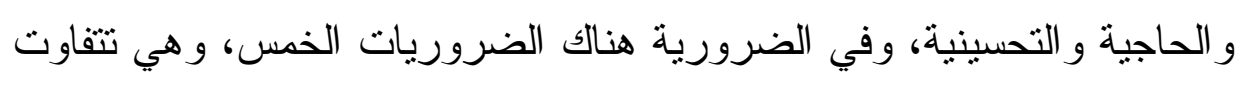

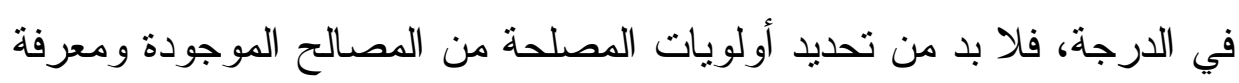

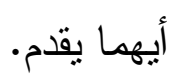

ثاتيًا: إن المصالح و المفاسد تختلط مع بعضها، فليس هناك مصلحة

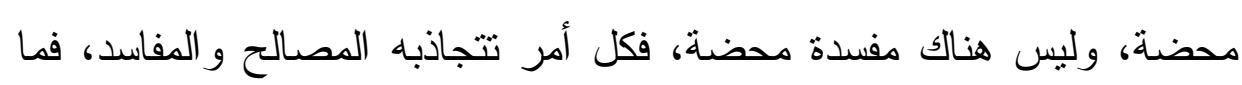

$$
\begin{aligned}
& \text { (1) المحصول، للر ازي (صـ (1) (1). }
\end{aligned}
$$

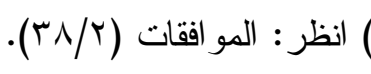

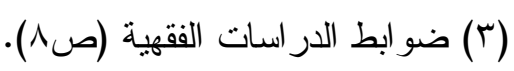




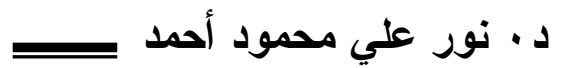

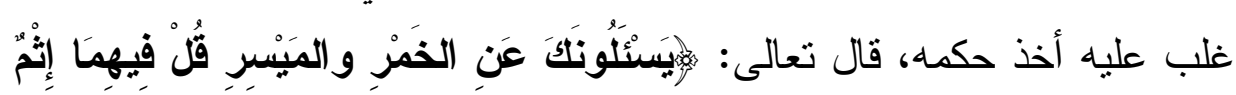

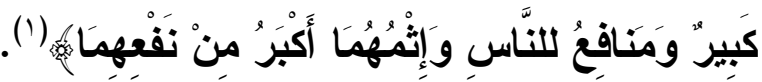

قال القرافي رحمه الله: استقر اء الثريعة يقضي أنه ما من مصلحة إلا مأل وفيها مفسدة، ولو قلَّت على البعد، و لا مفسدة إلا فيها مصلحة، وإن قلَّت على على

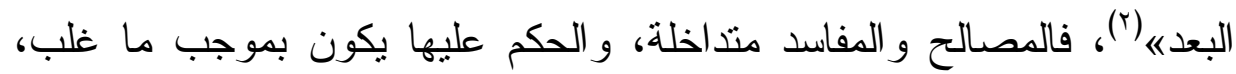
و لا يقوى على ذلك إلا أهل الارجة بالاجتهاد.

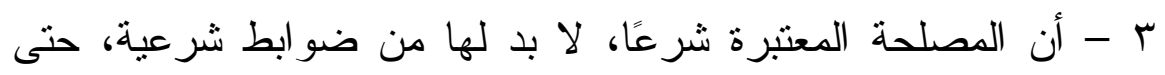
يحكم عليها بأنها مصلحة، ومن هذه الضوابط ما يلي:

ا- عدم معارضتها للنص وتقويتها له: قال الثيخ أبو زهرة: الأن المصلحة ثابتة حيث وُجد النص، فلا يمكن أن تكون هناك مصلحة مؤكدة أو غالبة والنص يعارضها، إنما هي ضلال الفكر أو نزعة الهوى أو غلبة الثهوة أو التأثر بحال عارضة غير دائمة أو منفعة عاجلة سريعة الزوال، أو تحقيق منفعة مشكوك في وجودها، وهي تقف أمام النص الذي جاء من الثارع

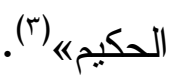

\section{فأينما وُجد شرع الله، فَثََّّ المصلحة، وليس العكس.}

\section{فالمصلحة المصادمة للنص هي مصلحة متوفَّمة، وليست حقيقية.}

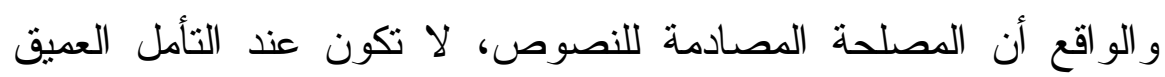
و التحليل الدقيق مصلحة حقيقية، بل هي مصلحة موهومة، زيَّنها لصاحبها

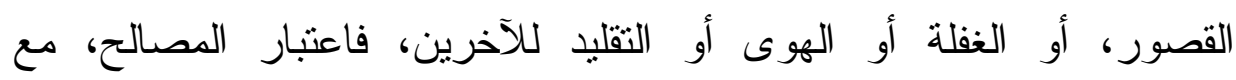
مصادمتها للنص، جر أة على الثرع، وقول على الله تعالى بغير علم.

$$
\begin{aligned}
& \text { (1) سورة البقرة، الآية (9 (Y)). }
\end{aligned}
$$

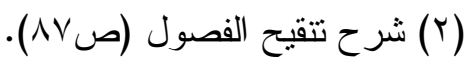

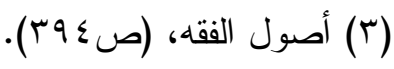




\section{تطبيقات فقهية}

وقد نص بعض المعاصرين على ضرورة مراجعة أنصبة الزكاة، وما

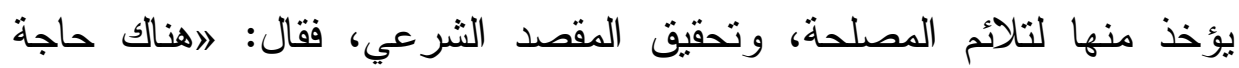

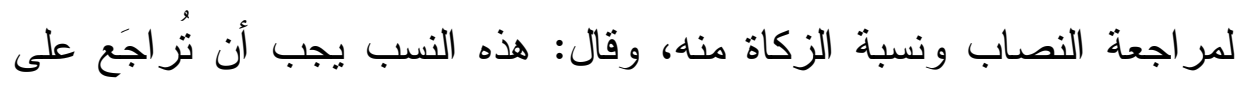

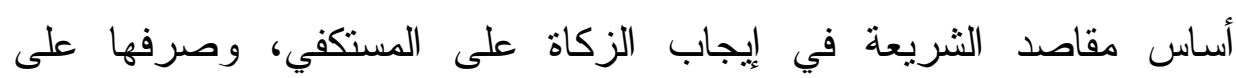

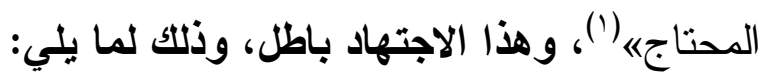

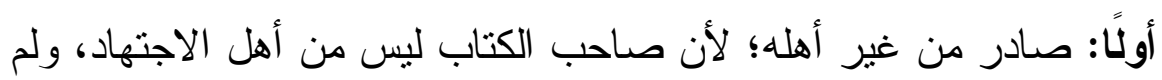
تتوفر فيه شروطه.

ثاتيًا: هو اجتهاد في غير محله؛ لأنه اجتهاد في مقابلة النصوص القطعية.

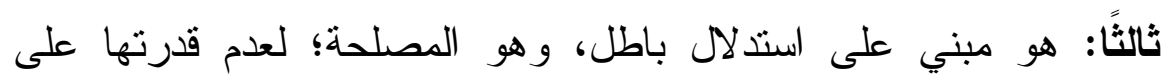

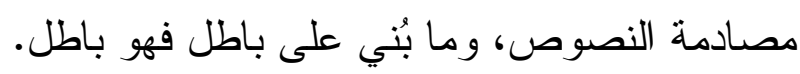

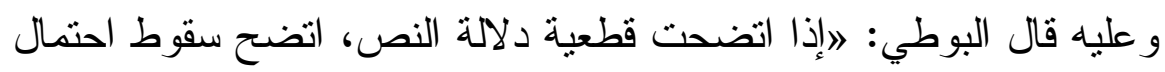

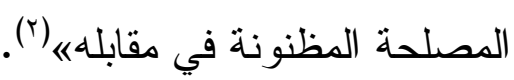

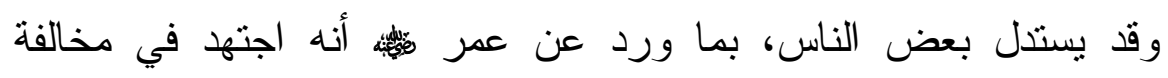
النص، فأسقط سهم المؤلفة قلوبهم من مصارف الزكاة الوارد في الآية، وهذا

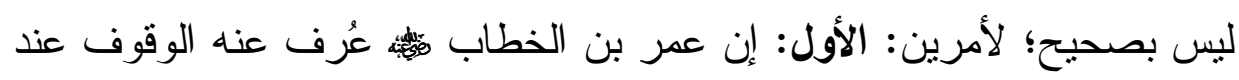

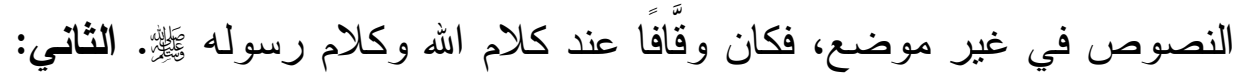

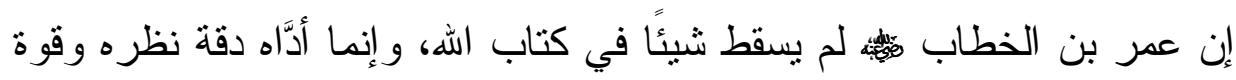

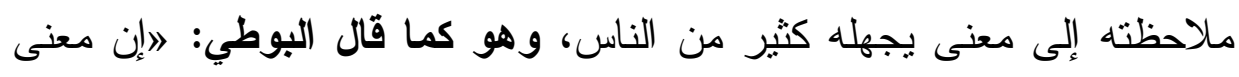

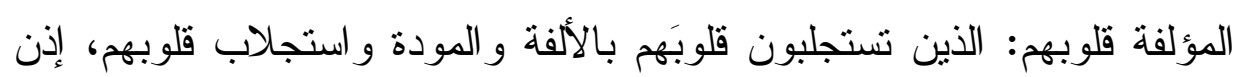

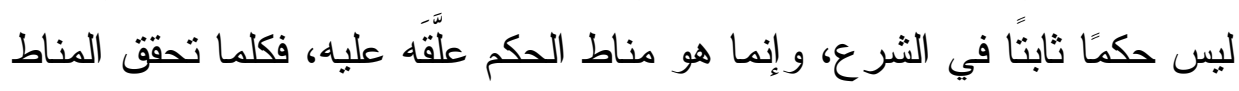

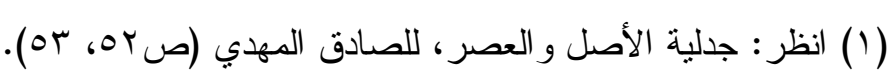

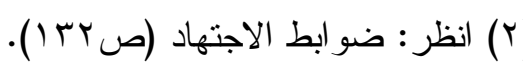


بـ تحقق الحكم المعلق به، و هو إعطاؤهم من الزكاة، فإذا فُقَّ، فُقَِ ما كان معلقًا

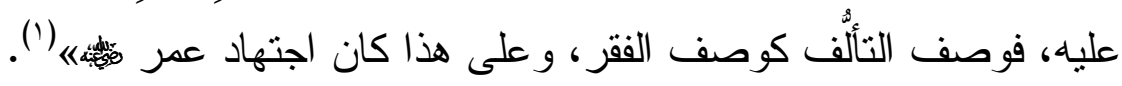

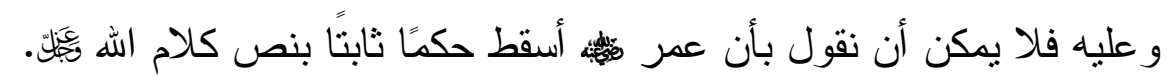

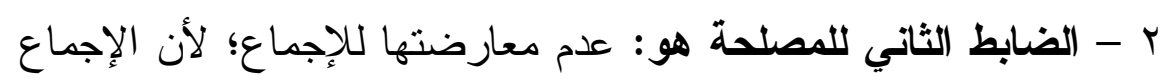

فيه عصمة الأمة من الخطأ، فيستحيل أن تُجْمع الأمة على باطل.

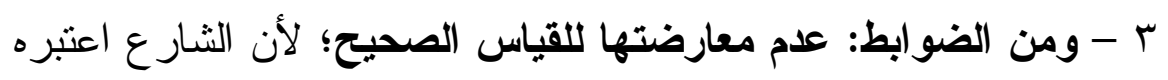
و اعتمده، مثال ذلك: قياس إيجاب الزكاة في العملة الورقية، قياسًا على الذهب و الفضة. وكذا قياس عدم جواز زكاة الدور و السيار ات، على عدم زكاة الخيل قوله

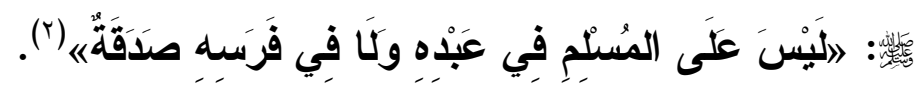

$$
\begin{aligned}
& \text { و العلة في ذلك: أنها مُعَدَّة لشخص الإنسان، وليس للبيع. }
\end{aligned}
$$

قال الحافظ ابن عبد البر: اوقال سائر العلماء: إنما معنى هذا الحديث: فيما يقتتى من العروض، ولا ير اد به التجارةه(r)، فكل شيء توفرت فيه هذه العلة، لا يجوز أخذ الزكاة منه و إن كانت مصلحة؛ لمصادمتها للقياس. ع - وكذا من ضوابطها: عدم تفويتها لمصلحة أهم منها أو مساوية لها، كما بينَّا سابقًا، لأن المصالح تثفاوت، فإذا أدى اعتبار ها إلى تفويت مصلحة أعظم منها ومساوية لها، فإنها لا تعتبر، وهذا الأمر لا يحتاج إلى دُربَة

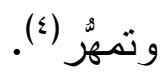

فإذا قلنا بأن الإمام يتصرف في الرعية بما يحقق المصلحة، نقول:

$$
\text { (1) (بظر : ضو ابط الاجتهاد (ص • r ا).) }
$$

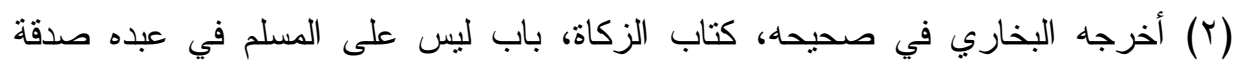

$$
\begin{aligned}
& \text {. (1 ( } 17 \leq \tau)(r \wedge \mu / 1)
\end{aligned}
$$

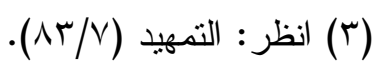

$$
\begin{aligned}
& \text { (انظر هذه الضو ابط بتوسع في: ضو ابط المصلحة المرسلة (صل V • ()). }
\end{aligned}
$$


أي: المصلحة المعتبرة شرعًا، بكل ما يتعلق بها، وليس مطلق المصلحة. المطلب الثاني: تصرف الحكام على الرعية منوط بالمصلحة العامة.

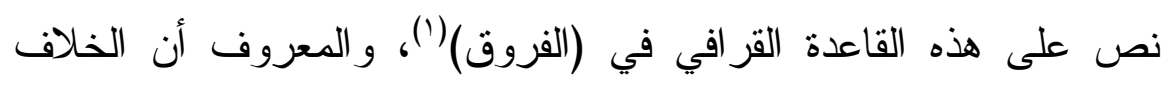
نتيجة طبيعية لاختلاف الناس في الأفهام وفي النظر، وقد امتلأت كتب الفقه

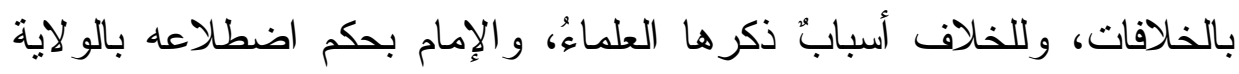

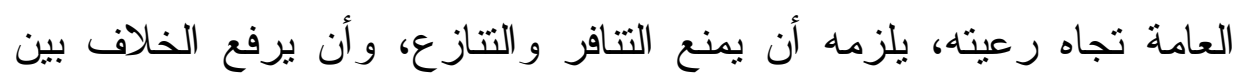

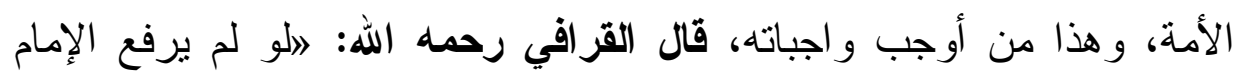

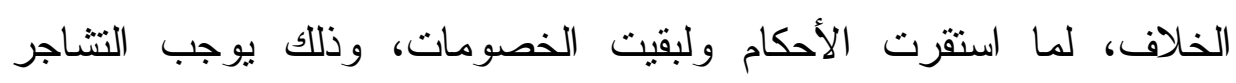

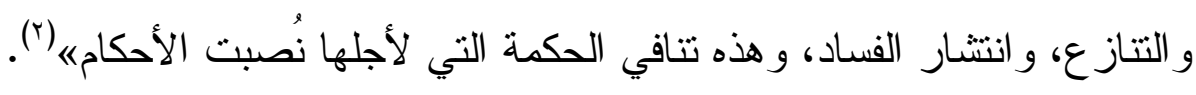

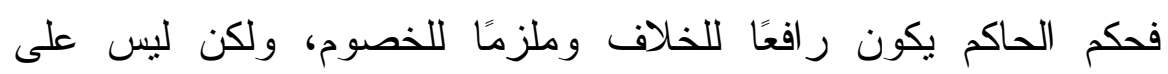

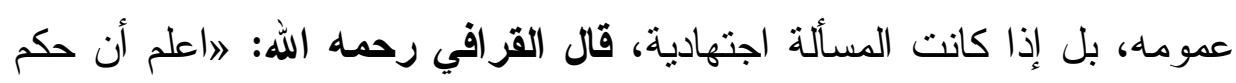

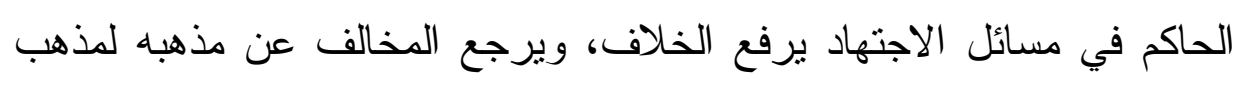

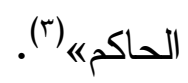

وفي هذا الكلام إثنارة إلى أن الخلاف الذي يرفعه الإمام هو الخلاف في لإني

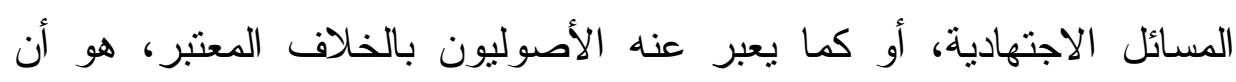

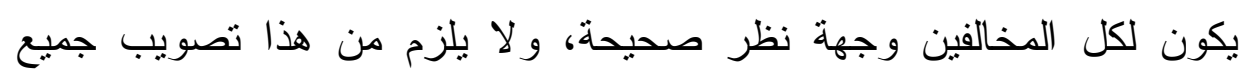

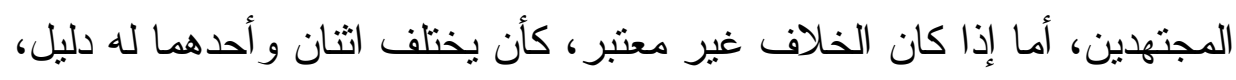

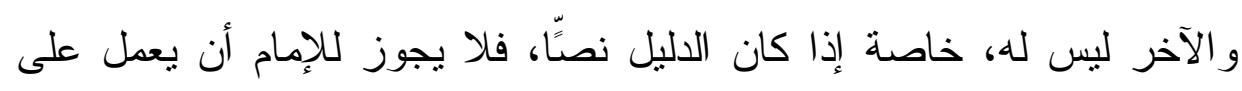

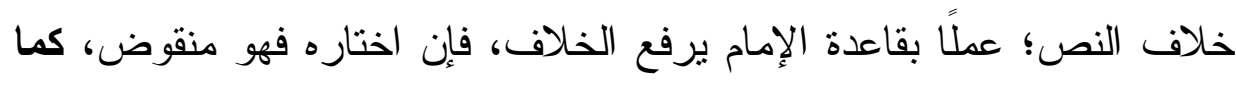

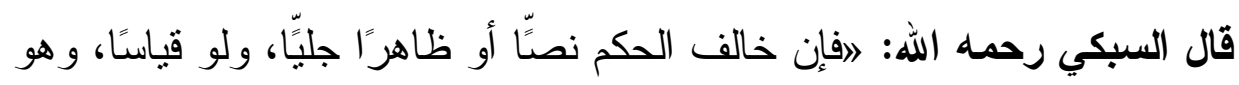

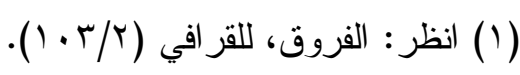

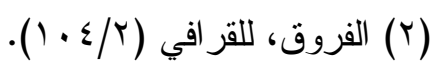

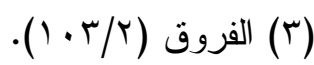




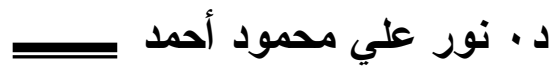

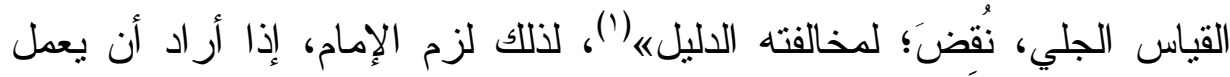

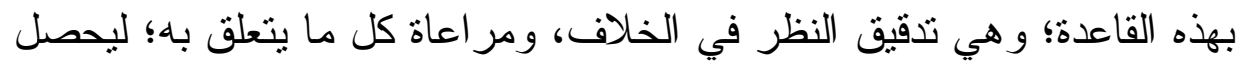

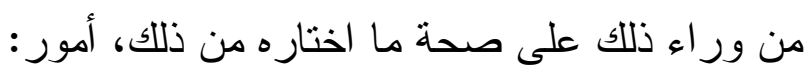
أولًا: لا بد من أن يكون الخلاف معتبرًا، كما ذكرنا سابقًا.

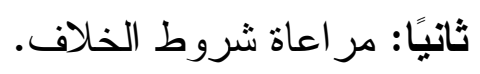

\section{يقول السيوطي: اولمراعاة الخلاف ثثلاثة شروط:}

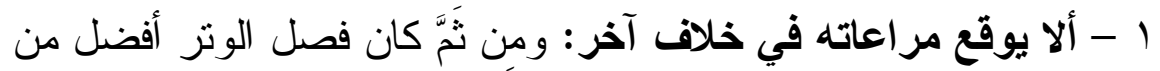

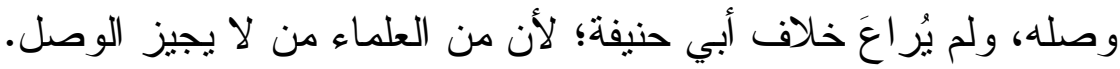

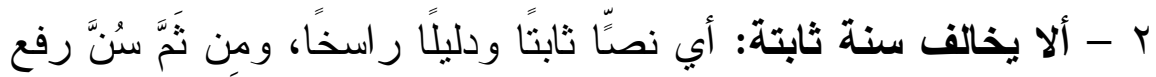

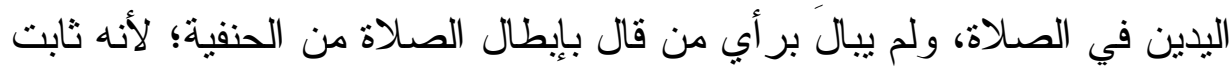
عن رسول الله

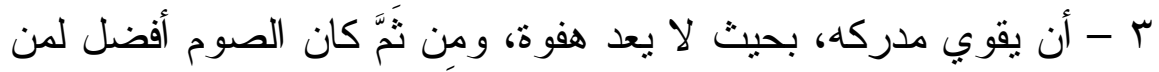

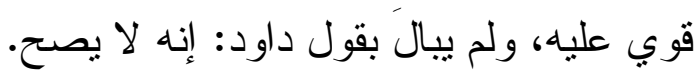

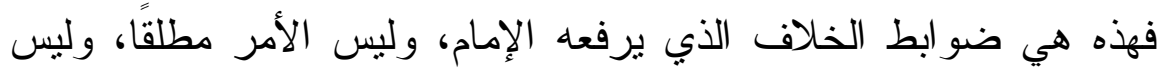

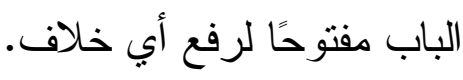
وقد أفتى مالك رحمه الله وقال: الساعي إذا أخذ من أربعين شاة رجلين

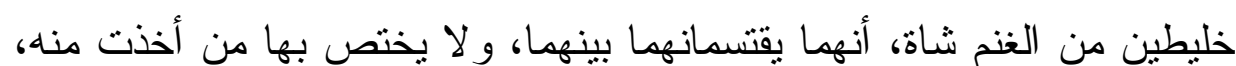
و علل مالك ذللك: بأنه حكم حاكم، فأبطل ما كان يفتي به (؟).

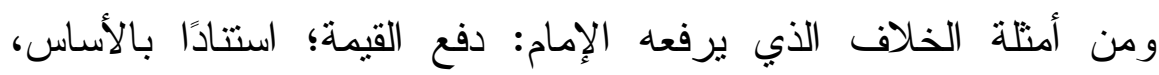

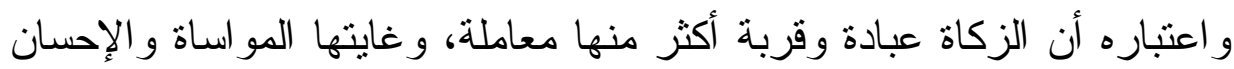

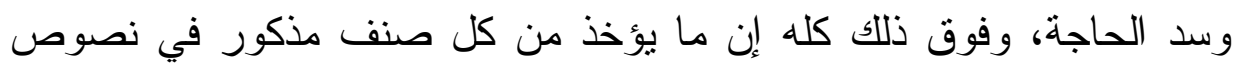

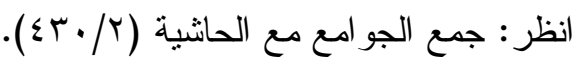

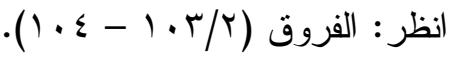




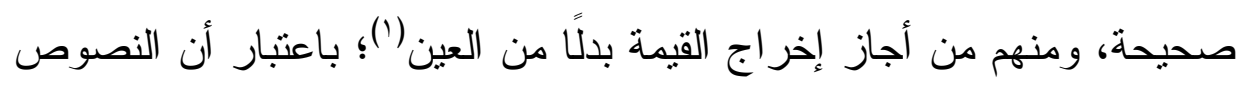

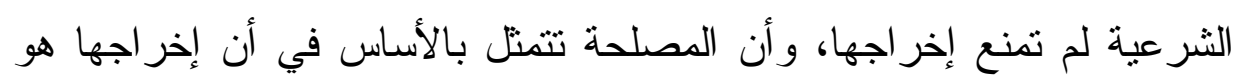

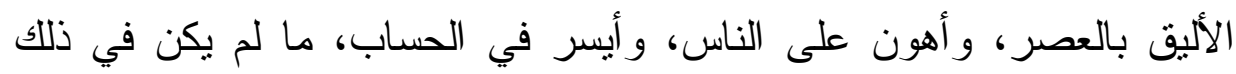

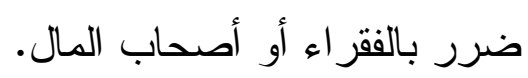

ثم إن الثريعة أجازت القيمة في الأثنياء مع وجود نظائر ها، كحديث

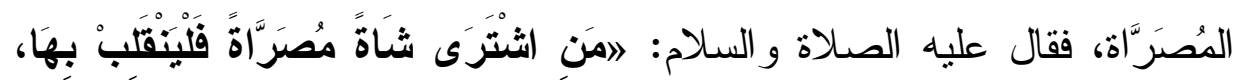

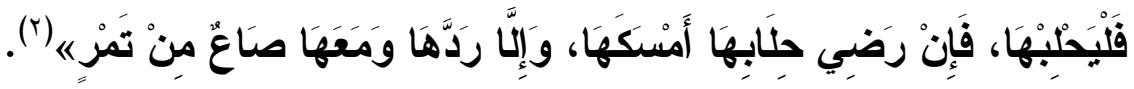

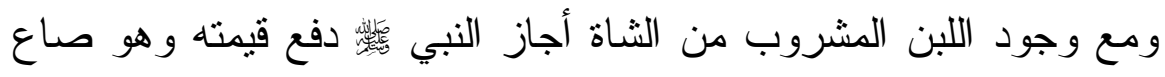

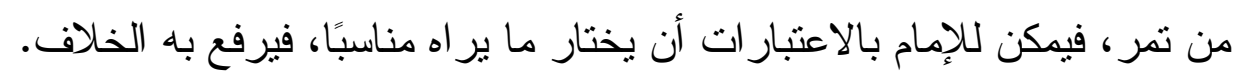

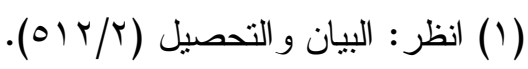

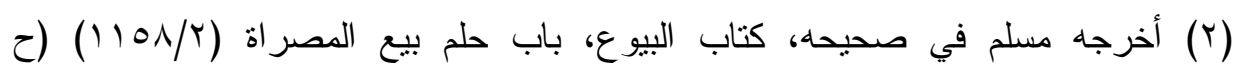


د. نور علي محمود أحمد بـ

\section{القصل الثالث: القواعد الفقهية لضبط المستجدات والنوازل}

نص على هذه القاعدة أغلب علماء الأصول(')، ومعنى هذه القاعدة: أن الوسائل التي لا تتم الو اجبات إلا بها تكون و اجبة، ولكن هذه القاعدة ليست على إطلاقها، و إنما لايها ما يجعلها تعمل في مو اضع محددة، وتحرير المقام: أن نقول: قال العلماء رحمهم الله: إن ما لا يتم الواجب إلا به ثلاثة أقسام: أولًا: قسم ليس تحت قدرة المكلف، كزو ال الشمس لوجوب الظهر ، وككون من تعينت عليه الكتابة مقطوع اليدين، وكحضور الإمام، و العدد الذي لا تصح الجمعة بدونه.

ثانيًا: قسم تحت قدرة العبد عادة، إلا أنه لم يأمر بتحصيله، كالنصاب لوجوب الزكاة، فهذان القسمان لا يجبان إجماعًا، كما قال ابن قدامة(r) و غيره. ثالثًا: قسم تحت قدرة العبد، وهو مأمور به، كالطهارة للصدلاة، و السعي للجمعة، وهذا و اجب على التحقيق. فعلى هذا، فمحل القاعدة ومكان الاستدلال بها هو القسم الثالث، وذللك بأن

$$
\text { يتو افر لهذا الثيء أمران: }
$$

الأول: الأمر به، أي: أمر بفعله.

الثاني: أن يكون تحت قدرته، وإلا فهو ليس بواجب، وأبنه أثبه بهذه القاعدة

$$
\text { قاعدة: للوسائل حكم المقصد (r). }
$$

و المراد بها كما قال العلماء: أن الأفعال نؤدي إلى المقاصد، ويختلف

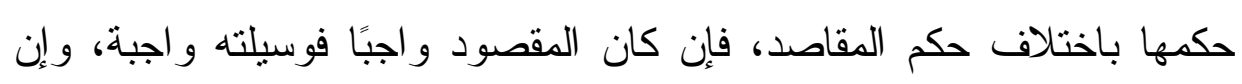

(1) انظر : روضة الناظر ، لابن قدامة (1/ (ب).

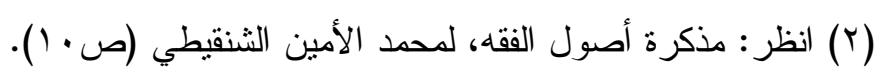

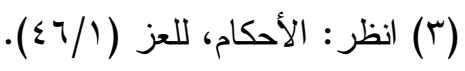




\section{تطبيقات فقهية}

كان محرمًا فوسيلته محرمة، وإن كان مندوبًا فوسيلته مندوبة، وإن كان مكروهًا

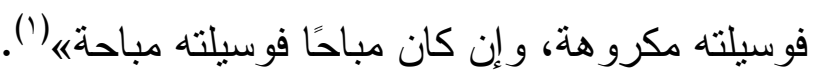

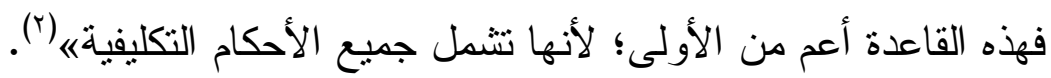

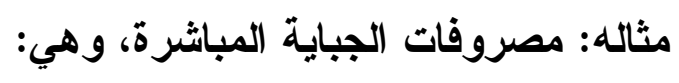

1- نفقات الزكوات العينية: كالجوالات، و التعبئة، و والوزن، و التخزين،

$$
\text { و التزحيل. }
$$

r- نفقات زكاة الأععام: كالعلف، و الترحيل، و السقاية، و الرعاية، الطبية.

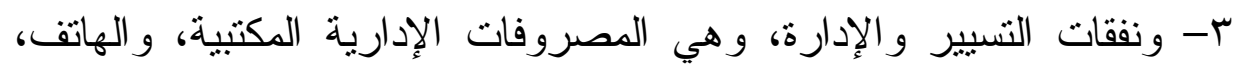
و الكهرباء، و الدياه، و الصيانة، و الإيجار ، و الإعلان.

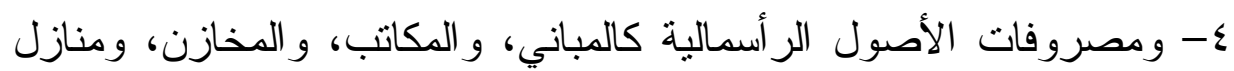
العربات، وغير ذللك. فهل هذه تنطبق عليها قاعدة: 》اما لا يتم الواجب إلا به فهو واجب)، أم

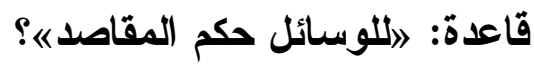
و الذي يجعل المسألة أكثر تعقيدًا: قاعدة: 》ما لا يتم ترك الحر ام إلا بتركه،

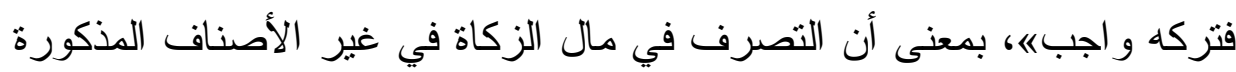

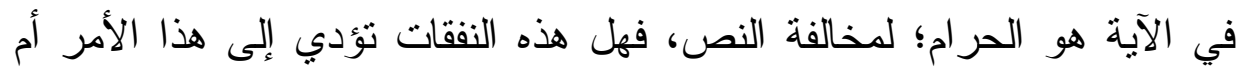
لا؟ ومع بروز هذا الاحتمال يحصل التعارض.

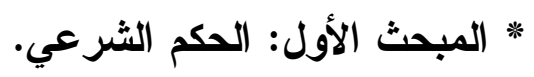

تعريف الحكم لغة: العلم و الفقه و القضاء بالعدل، وهو مصدر حكم يحكم،

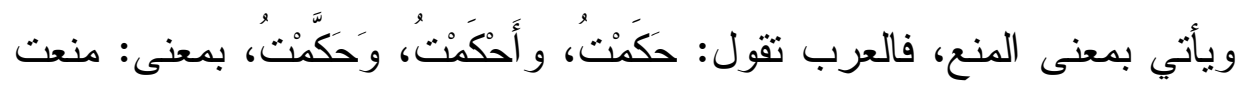

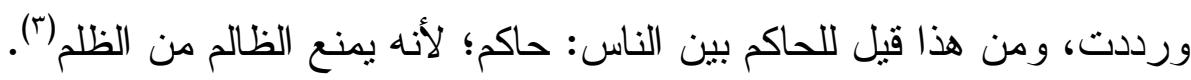

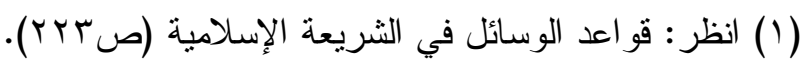

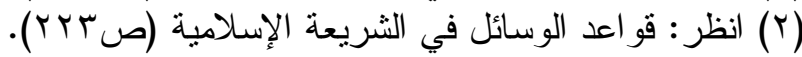

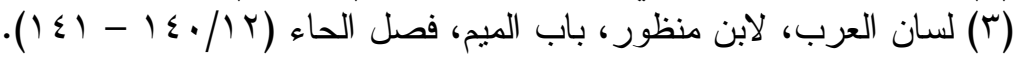

$$
\begin{aligned}
& -1 \leqslant 7-
\end{aligned}
$$


د. نور علي محمود أحمد بـ

الشرعي لغة: اسم منسوب إلى الشرع، وهو ما شرعه الله لعباده، ومتله

الثريعة: وهي ما شرع اله لعباده و الظاهر المستقيم من المذاهب(").

فكل ما شرع الله للعباد شريعة من الصوم و الصلة و الحج و النكاح و غيره،

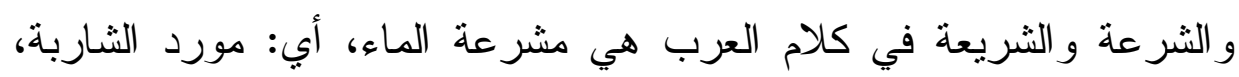
التي يقصدها الناس، فيشربون منها ويستقون، و العرب لا تسميها شريعة، حتى يكون الماء لا انقطاع له، ويكون ظاهرًا معينًا (r). الحكم الشرعي اصطلاحًا: عرف الأصوليون الحكم الثرعي بتعريفات كثيرة، ننتقي بعضها، ثم نخلص إلى التعريف المختار . فعرفه صفي الاين البغدادي: بأنه قضاء الثار ع على المعلوم بأمر ما نطقًا

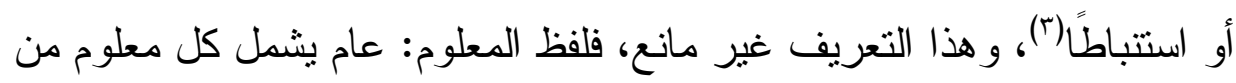
العلميات و العمليات، وقوله: بأمر ما: عام شمل الأو امر و النو اهي و الأخبار

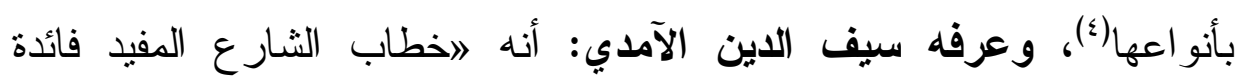
شرعيةه|()، وهذا التعريف غير مانع أيضًا، أما جمال الدين الإسنوي، فعرفه الأه بأنه: "خطاب الله تعالى المتعلق بأفعال المكلفين، بالاقتضاء أو التخييره(؟). وبنفس التعريف عرَّفه سر اج الدين الأرموي الثافعي في كتابه (التحصيل من المحصول)، وكذلك العلامة عبد العلي الأنصاري اللكنوي الحنفي، في

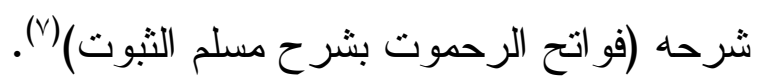

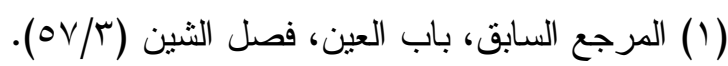

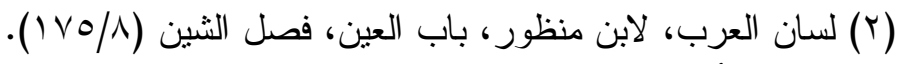

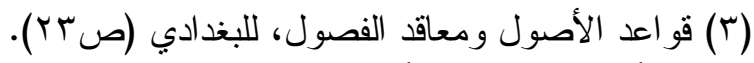

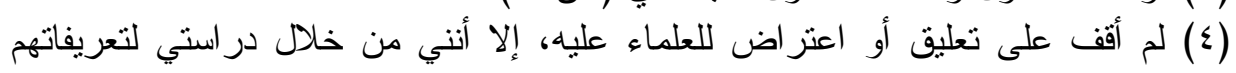
استتتجت هذا الاعتر اض.

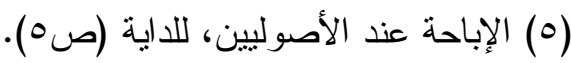

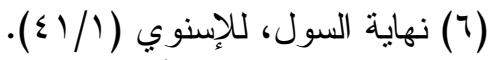

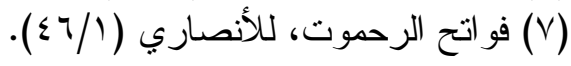




\section{تطبيقات فقهية}

وهذا التعريف مانع، وإن كان غير جامع؛ لأنه لا يشمل الحكم الوضعي؛

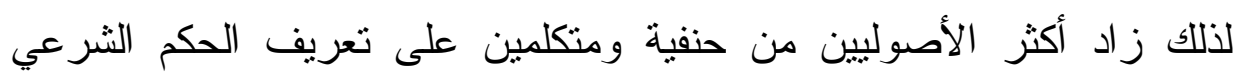

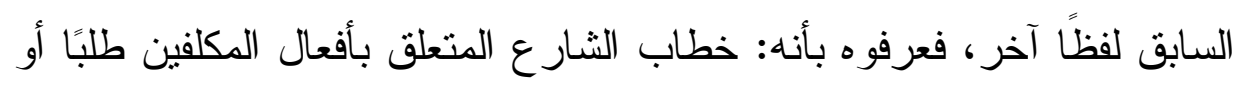

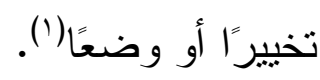

* المبحث الثاني : أقسام الحكم الثرعي. للعلماء في تقسيم الحكم الثرعي تقسيمات منتو عة عند الحنفية، وكذلك عند

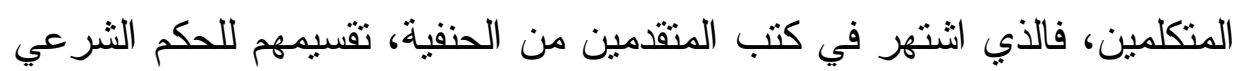
إلى رخصة و عزيمة(؟).

وقسمه المتأخرون منهم إلى حكم تكليفي، وحكم وضعي (r).

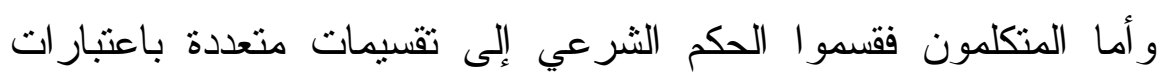

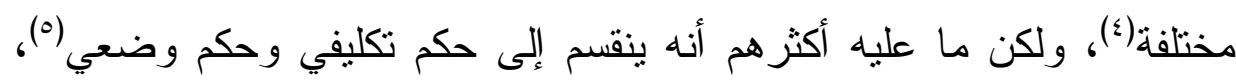
وأما المتكلمون: فقسموا الحكم الثرعي إلى تقلى تقسيمات متعددة، باعتبارات

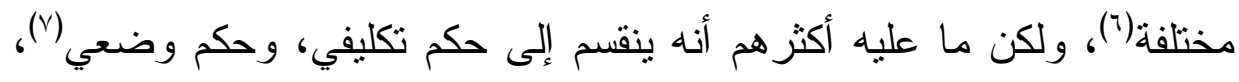

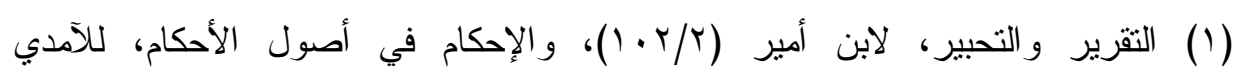
( )

(r) (انظر: كنز الوصول على معرفة الأصول، للبزدوي (1)/ (1)، وأصول السرخسي

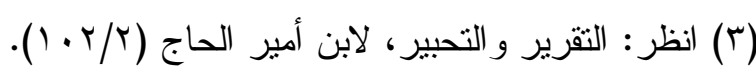

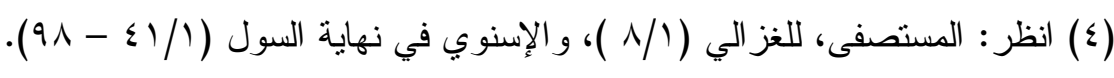

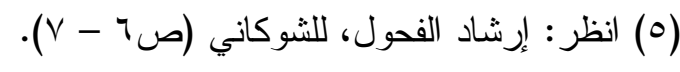

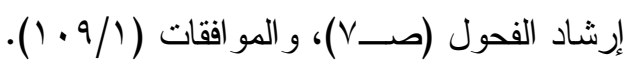

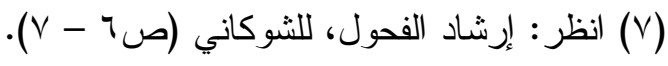

$-1 \leqslant \wedge-$ 


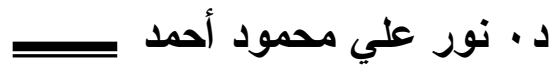

وما استقر عليه من تقسيم للحكم الثرعي عند الحنفية و المتكلمين، أنه ينقسم إلى قسمين: حكم تكليفي، وحكم وضعي (').

- حكم تكليفي: وهو خطاب الثار ع المتعلق بأفعال المكلفين، اقتضاءً أو وضع

تخيير"|(r)

\section{حقيقة الحكم التكليفي، وأثز الاختلاف فيه على الفروع:}

تعريف الحكم التكليفي:

التكليفي لغة: 》اسم منسوب إلى التكليف، و التكليف مصدر من كلف يكلف

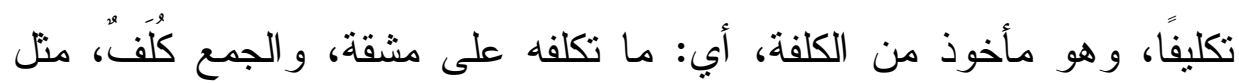
غُرْفَة وغرَفَ، و التكاليف المشاق أيضًا، و الو احدة تكلفة، وكلفت الأمر من [باب ماب تعب] حملته على مشقة، ويتعدى إلى مفعول ثان بالتضعيف، فيقال: كلفته الأمر ، فتكلفه، منل حملته فتحمله وزنًا ومعنى، على المشقةه (ّ). الحكم التكليفي اصطلاحًا:

لم يكن للحكم التكليفي حد عند كثير من الأصوليين المتقدمين من الحنفية

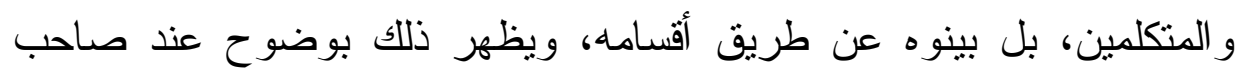
كتاب 》كنز الوصوله، وصاحب 》أصول السرخسي" من الحنفية، حيث جعلا

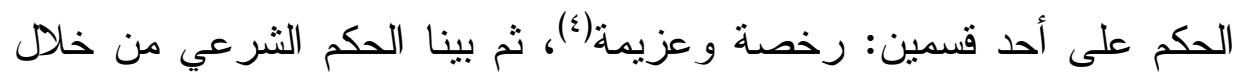
شرح هذين القسمين، وكذلك فعل بعض المتكلمين، كصاحب 》الورقاته، حيث

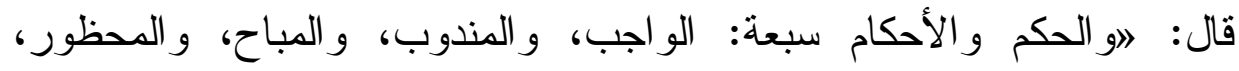

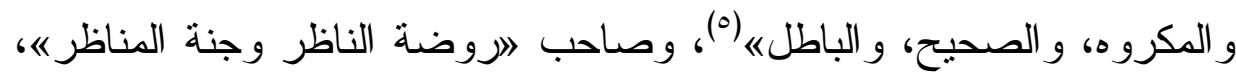

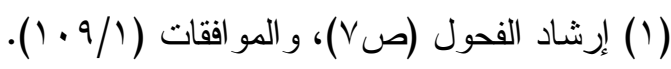

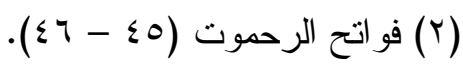

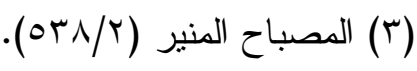

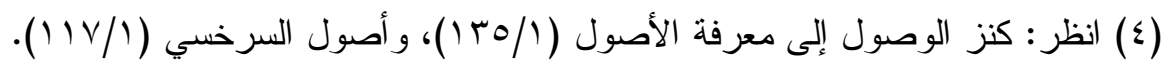

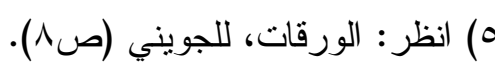




\section{تطبيقات فقهية}

قال: "احقيقة الحكم و أقسامه: و اجب، ومندوب، ومباح، ومكروه، ومحظور 《(')،

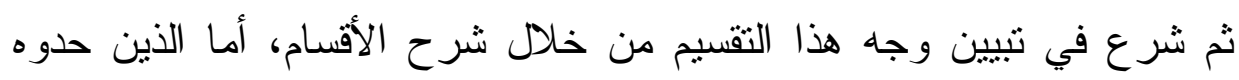

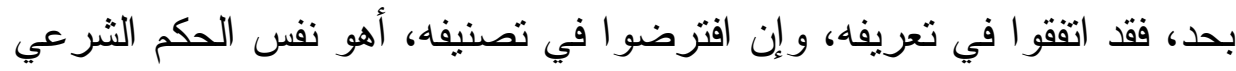
أم هو جزء منه؟

\section{والتفصيل كالتالي:}

أولًا: من الأصوليين من اعتبر أن الحكم التكليفي هو نفس الحكم الثرعي،

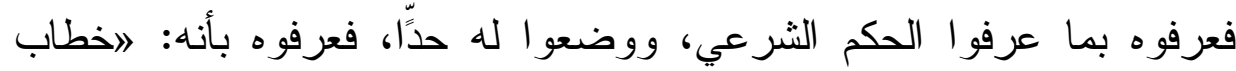

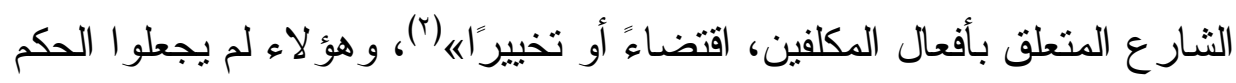

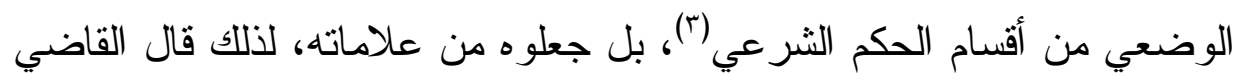

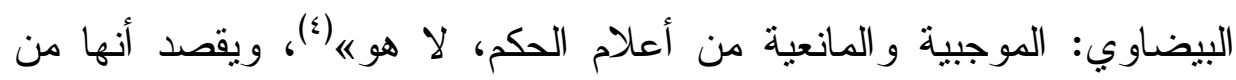

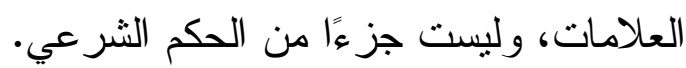

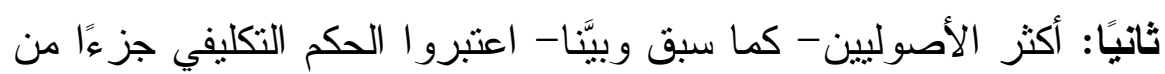

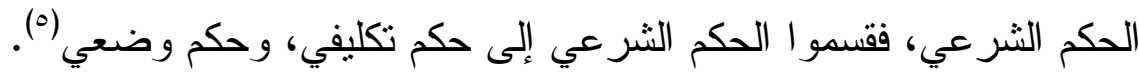

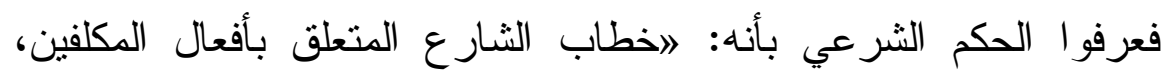

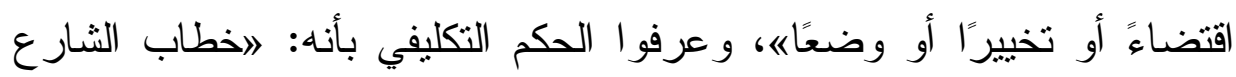

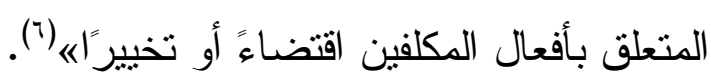

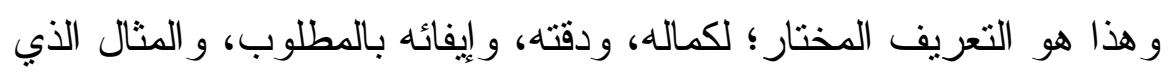

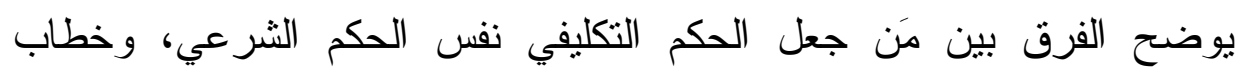

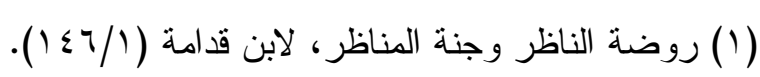

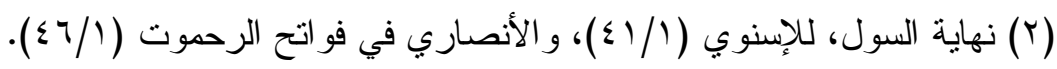

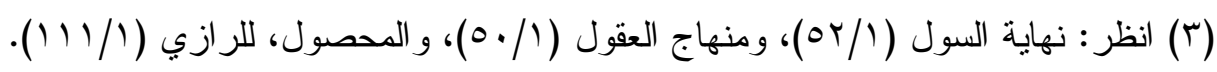

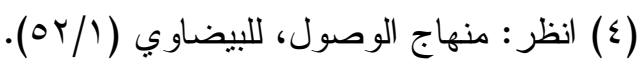

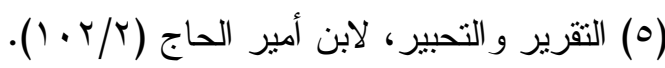

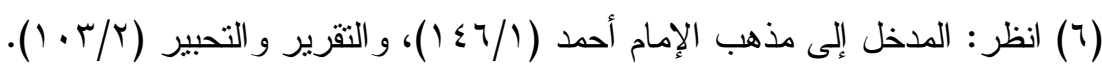

$$
\begin{aligned}
& -10 \cdot-
\end{aligned}
$$




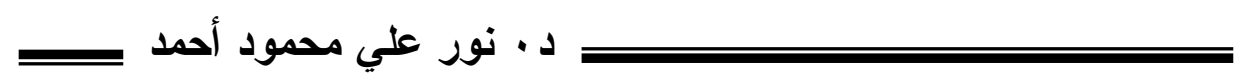
الوضع علامات عليه، ومَن جعل الحكم التكليفي جزءًا من الحكم الثرعي، كما

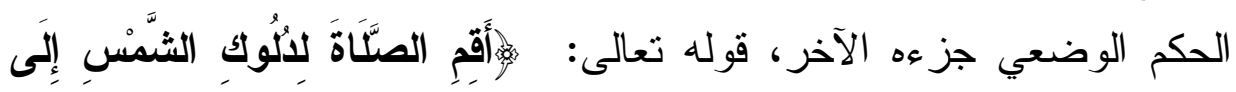

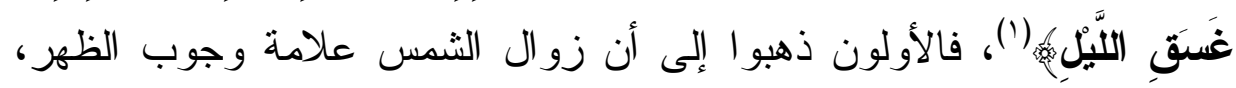
أي: علامة معرفة أن سبب إيجاب الصلاة هو زوال الثمس، وهذه العلامة

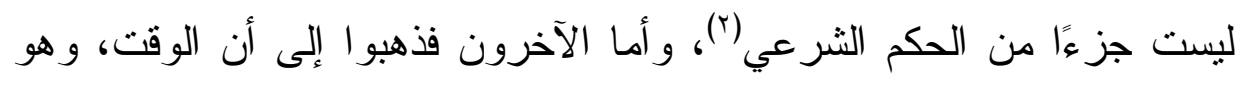
وقت زو ال الثمس سبب لإيجاب إقامة الصلاة، وهذا السبب جزء من الحكم

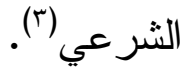

ب - من عرَّن الحكم الشرعي بتعريف الفقهاء، عرَّف الحكم التكليفي بأنه:

أثز خطاب الثار ع المتعلق بأفعال المكلفين اقتضاءً أو تخييرًاءع). والفرق بين تعريف جمهور الأصوليين والفقهاء يتضح بالمثال التالي:

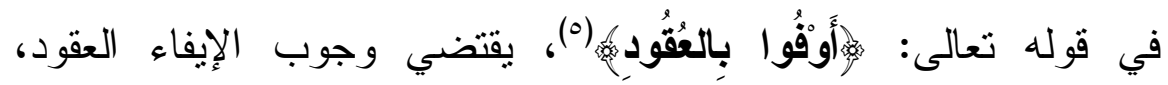
فالخطاب نفسه هو الحكم في اصطلاح الأصوليين، ووجوب الإبقاء هو الحكم في إصطلاح الفقهاء(").

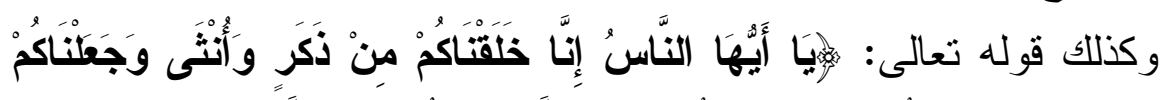

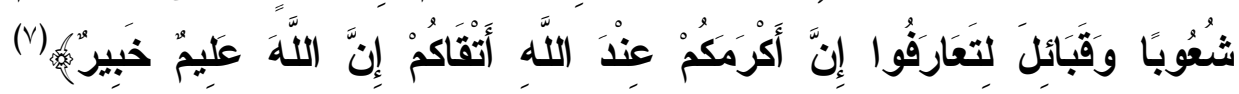

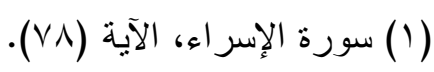

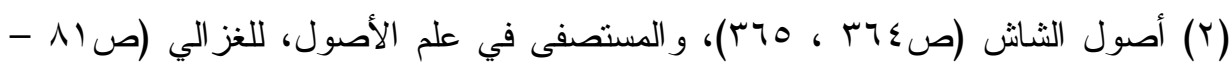

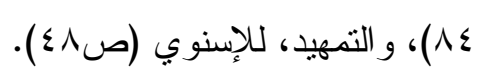

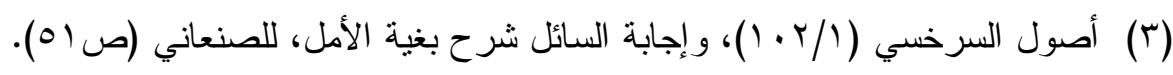

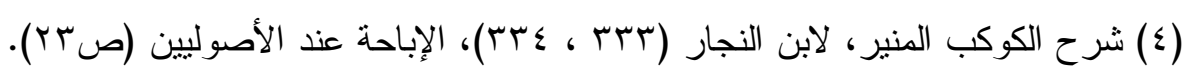

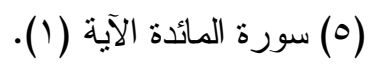

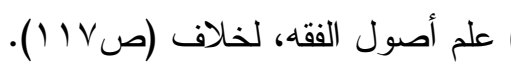

(V) سورة الحجرات، الآية (r) (1). 


\section{تطبيقات فقهية}

الخطاب نفسه بنصه هو الحكم عند الأصوليين، وحرمة الإقدام على هذه الأفعال هي الحكم عند الفقهاء) ('). * المبحث الثالث: العلاقة بين الحكم التكليفي والحكم الوضعي: يختلف الحكم التكليفي و الثرعي من حيث حقيقتهما ومدلولهما، إلا أنهما قد

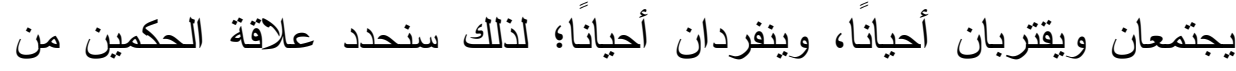

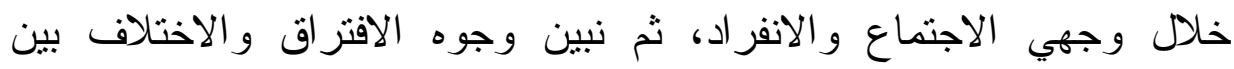

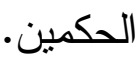

\section{أولًا: وجوه اجتماع و انفراد الحكم التكليفي عن الوضعي:}

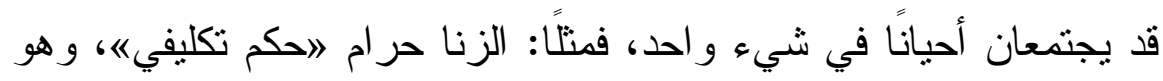
سبب للحد "حكم وضعي" وقد ينفرد خطاب الوضع كأوقات العبادات، وكون

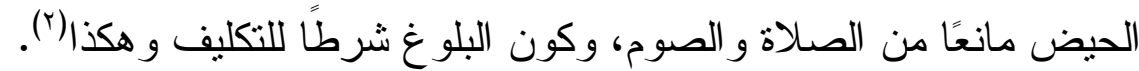

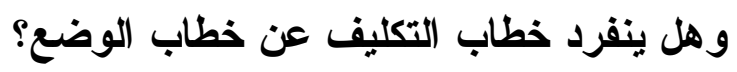

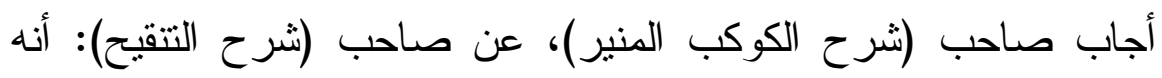
قال: لا يتصور ؛ إذ لا تكليف إلا له سبب أو شرط أو مانع، وكذلك قال الطوفي

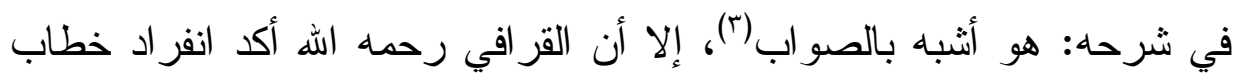

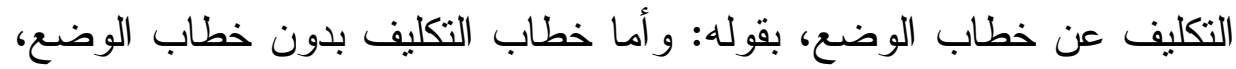

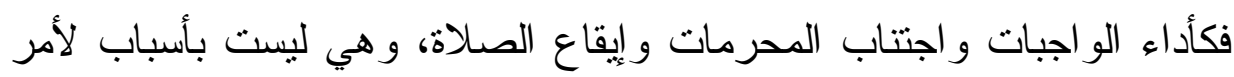

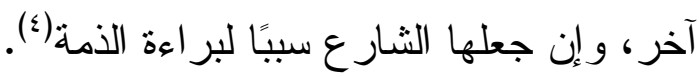

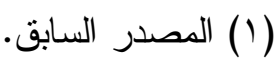

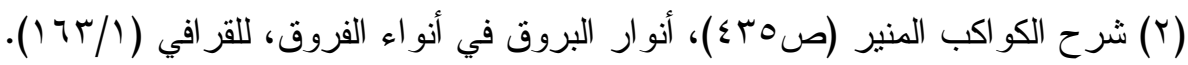

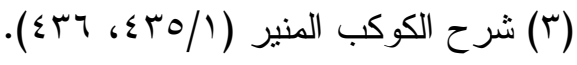

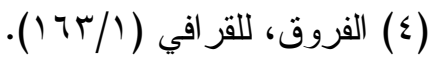




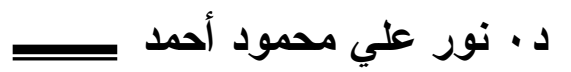

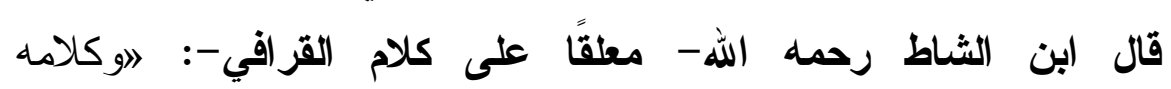

صحيح" (') (1) (1)

و أر اد القر افي من هذا الكلام أن يلفت الانتباه إلى أن أداء الو اجب وتجنب

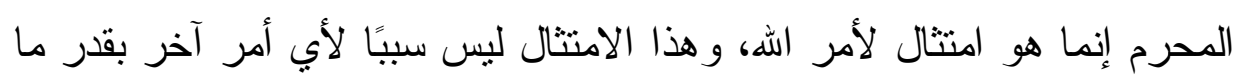

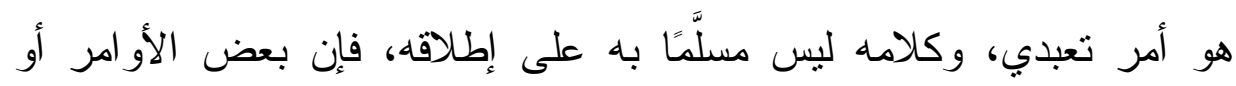

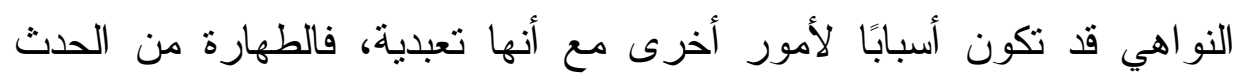
الأكبر واجبة وهي من الأمور التعبدية، لكن عدمها مانع من الصلاة، ولبس الذهب للرجال محرمًا، وهو أمر تعبدي، ولكنه سبب للتعزيز ، وكما أن الحكم

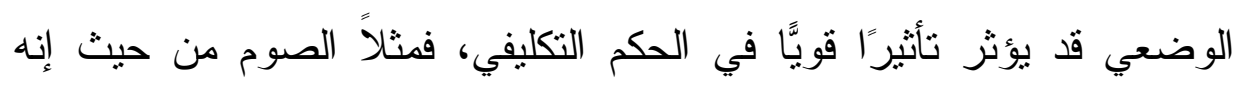
صوم مشروع، سو اء كان فرضًا أم نفلًا، لكن من حيث الجملة لكن من حيث ليث إيقاعه إن وقع مقرونًا بشرط فاسد، أو بزيادة في المال الربوي ممنوع) (؟). ثانيًا: وجوه الافتراق والاختلاف بين كلام الحكمين، وهي تتمثل في عدة برة

نقاط:

\section{أب - من حيث الحقيقة:}

أ - الحكم التكليفي مقصود به طلب فعل من المكلف، أو كفه عن فعل أو

تخييره بين الفعل و الكف، و أما الوضعي فليس مقصودًا به الطلب أو التخيير، أله و إنما المقصود به بيان أن هذا الثيء سبب لهذا المسبب، أو أن هذا شرط لهذا المشروط، أو أن هذا مانع من هذا الحكم()، كما أن الحكم الوضعي خاص بما لها رتب الحكم فيه على وصف، أو حكمة، إن جوزنا التعليل بها، فلا يجري في هي الأحكام المرسلة غير المضافة إلى الأوصاف، ورلا في الأحكام التعبدية التي لا لانهان

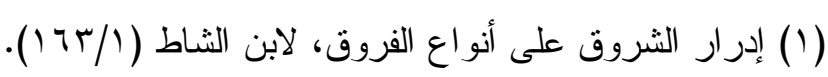

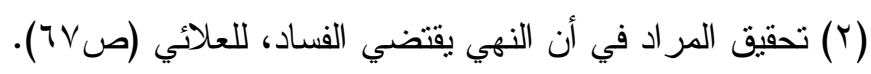

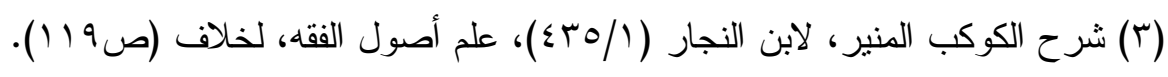


يعقل معناها؛ لهذا لو أحرم شخص ثم جن ثم قتل صيدًا، لا يجب الجزاء في

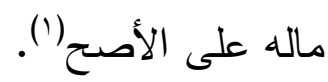

ب - خطاب التكليف هو الأصل، فالأصل أن يقول الثنارع: أوجبت

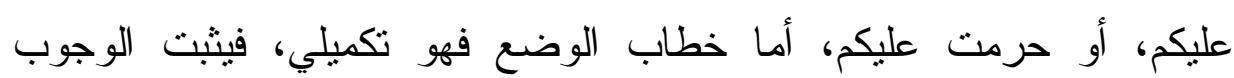
بخطاب التكليف، و إن لم يذكر خطاب الوضع (؟).

\section{r - من حيث التعليق:}

الحكم التكليفي لا يتعلق إلا بفعل المكلف، و الوضعي يتعلق بفعل المكلف

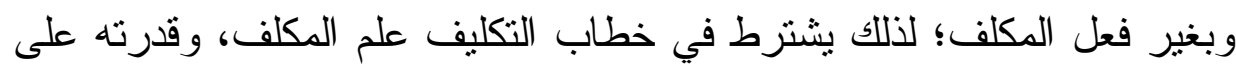
الفعل، وكونه من كسبه، كالصلاة و الصوم ونحو هما. أما خطاب الوضع فلا يشترط فيه شيء من ذللك، فلا يشترط العلم، كالنائم

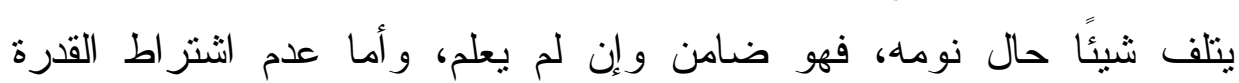
و الكسب، فكالدابة تتلف الثيء فيضمن صاحبها، و إن لم يكن الإتلاف منه (†).

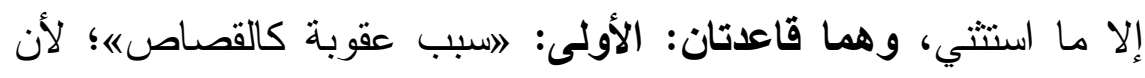
القصاص لا يكون إلا بعد تعدد للقتل، والثانية: انقل ملك كالبيع و الهبة الأبة

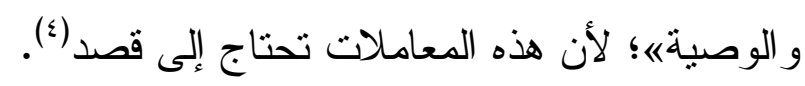
وعلق على ذلك ابن الثاط: بأن القاعدتين غير مستثنيتين، و إنما ازدورج فيها خطاب التكليف و الوضع، وكلامه وجيه. r - من حيث مرعاته لأحوال المكلفين:

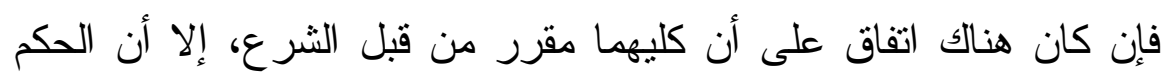

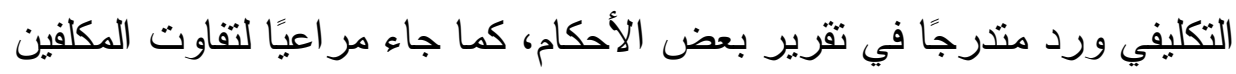

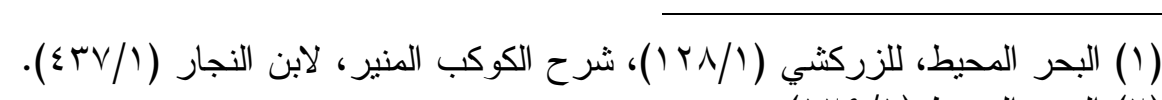

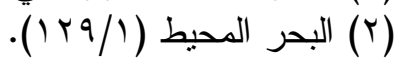

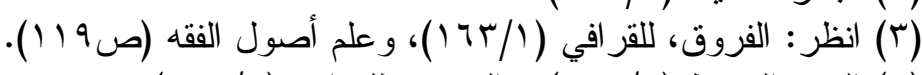

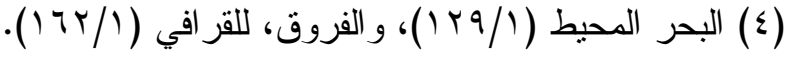

$$
\begin{aligned}
& -10 \leqslant-
\end{aligned}
$$




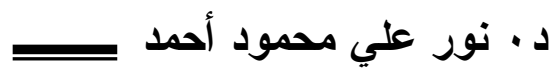

في الصفات المقتضية لتفاوت التكاليف، كالعجز، و القدرة، و الذكورة، و الأنوثة، و الحضور، و الغيبة، و الرق، و الحرية، و القوة، و الضعف، و البعد، و القرب، و الغنى، و الفقر، و الضرورة، و الرفاهية، فإن الله تعالى شرع لكل من هؤلاء

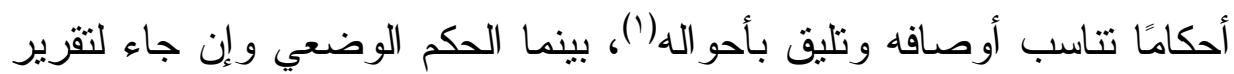
المصالح، إلا أنه لا يظهر فيه مثل الوصف الذي سبق وقدمناه، ومع أن الحنفية و المتكلمين اتفقو افي تعريف الحكم التكليفي، إلا أنهم اختلفوا في الطريق الذي يثبت به الحكم التكليفي، مما ترتب عليه خلاف في الفروع. 


\section{تطبيقات فقهية}

\section{الخاتــمة}

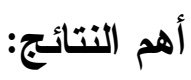

بعد تمام ما أردت جمعه في موضوع لاتطبيقات فقهية على جواز تغيير

الأحكام الاجتهادية «، إليك أهم النتائج التي تم التوصل إليها، وهي كما يلي:

أولًا: دلت نصوص الكتاب و السنة والإجماع، على عدم الاجتهاد في مورد

$$
\text { النص، من كتاب أو سنة أو إجماع. }
$$

ثَانيًا: قاعدة الاجتهاد لا يُنقض بالاجتهاد.

ثالثًا: من شروط قاعدة الاجتهاد: عدم مخالفتها لنصوص الكتاب أو السنة

أو إجماع أو المصلحة العامة، وألا ثقوم على بينة مزورة أو ظلم أو جيف.

رابعًا: اتفق الفقهاء على نقض الاجتهاد بالأدلة القطعية، دن نصوص هرو

الكتاب و السنة المتو اترة.

خامسًا: جواز تغير الأحكام الاجتهادية بتغير الزمان.

سادسًا: تصرف الإمام على الرعية منوط بالمصلحة العامة، و الإمام يرفع

الخلاف. 
د. نور علي محمود أحمد بـ

فهرست المصادر والمراجع

\begin{tabular}{|c|c|c|c|}
\hline الطبعة & المؤلف & اسم الكتاب & p \\
\hline 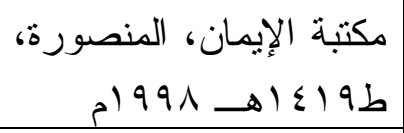 & البخاري & صحيح البخاري & 1 \\
\hline محمد فؤ اد الحلبي، تحقيق & 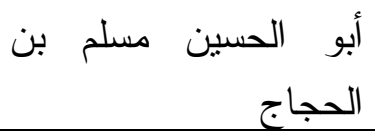 & صحيح مسلم & r \\
\hline 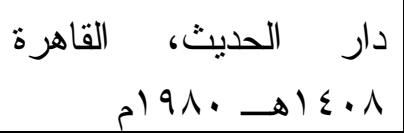 & سليمان بن الأشعث & سنن أبي داود & $r$ \\
\hline 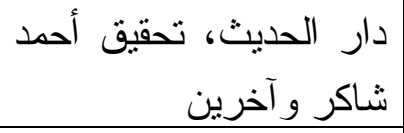 & عحمد بن عيسى التزمذي & سنن الترمذي الصحيح وهو & $\varepsilon$ \\
\hline محمد فؤ اد الحلبي، تحقيق & محمد بن يزيد القزويني & سنن ابن ماجه & 0 \\
\hline 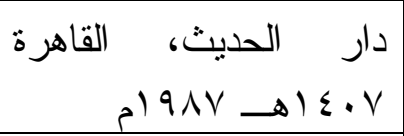 & أحمد بن شعيب النسائي & سنن النسائي & 7 \\
\hline 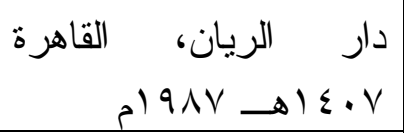 & عبداله بن عبد الرحمن & سنن الدارمي & v \\
\hline دار الحديث، القاهرة & ماللك بن أنس & موطأ مالك & $\Lambda$ \\
\hline شؤسسة الرسالة، تحقيق & أحمد بن محمد الشيباني & مسند الإمام أحمد & 9 \\
\hline 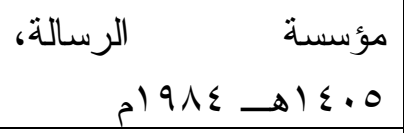 & سليمان أحمد & مسند الشاميين & 1. \\
\hline 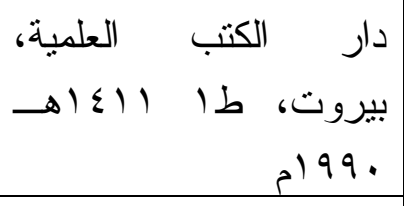 & أبو عبد الله الحاكم محمد الله النيسابوري & الصحيحترك & 11 \\
\hline دار الكتب العلمية، بيروت & أحمد بن الحسين البيهقي & السنن الكبرى & Ir \\
\hline 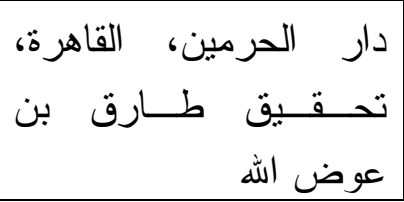 & سليمان & المعجم الأوسط & ir \\
\hline
\end{tabular}




\begin{tabular}{|c|c|c|c|}
\hline 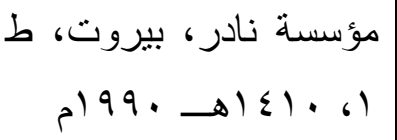 & علي بن الجعد الجوهري & مسند ابن الجعد & $\varepsilon$ \\
\hline 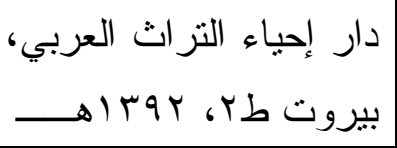 & 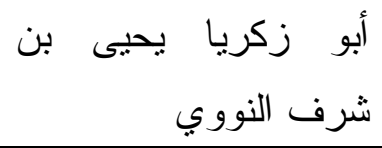 & صحيح مسلم بشرح & 10 \\
\hline دار المعرفة، بيروت & أحمد بن حجر العسقلاني & فتح الباري شرح & 17 \\
\hline مطبعة السنة المحمدية & ابن دقيق العيد & عمدة الأحكام الأحكام شرح & IV \\
\hline 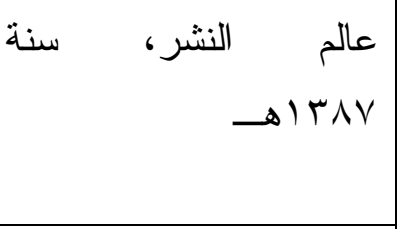 & أله البو عمر يوسف بن عبد & التمهيد لما في الموطأ & 11 \\
\hline 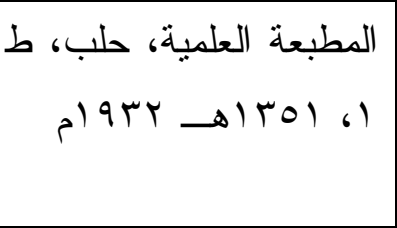 & أبو سليمان & شعالم السنن و وهو & 19 \\
\hline دار الكتب العلمية، بيروت & محمد عبد الرحمن & شرفة الأحوزي، & $r$. \\
\hline بيروت، طار & محمد شيمس الحق آبادي أبو الطيب & عون المعبود & r \\
\hline 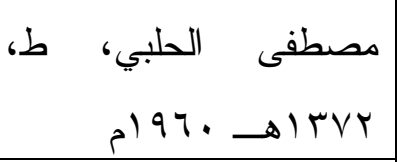 & محمد بن إسماعيل & سبل السلام & rr \\
\hline سار & محمد بن علي الشوكاني & ن الأوطار & $r r$ \\
\hline دار صادر ، بيروت & ابن منظور & ل لسان العرب & $r \varepsilon$ \\
\hline دار الكتب العلمية (99 ام & تاج الدين السبكي & الأشباه و النظائر & ro \\
\hline
\end{tabular}

$-101-$ 


\section{د. نور علي محمود أحمد}

\begin{tabular}{|c|c|c|c|}
\hline السعودية، $\quad$ دارين $\quad$ الجوزي، & 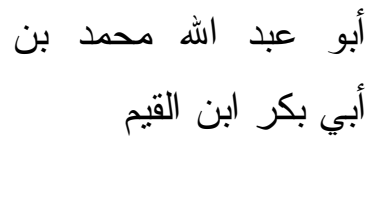 & 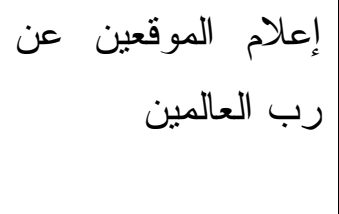 & r \\
\hline 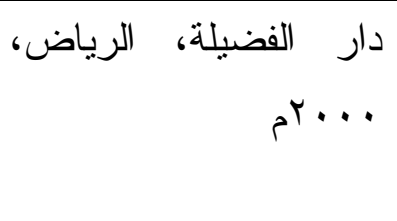 & محمد بن علي الثوكاني & 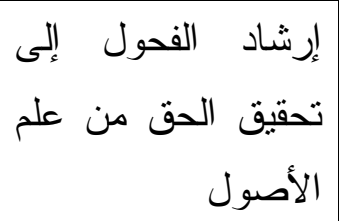 & rV \\
\hline لجنة إحباء المعارف، & 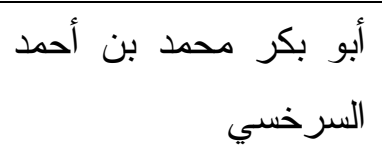 & ل ل ل السرخسي & rA \\
\hline دار المعرفة، بيروت & شمس الدين السرخسي & المبسوط & rq \\
\hline مؤسسة الرسالة & فخر الدين الرازي & أصول الفقهول في علم & $r$. \\
\hline بوار الصفوة، الغردقة، & محمد بن بهادر & 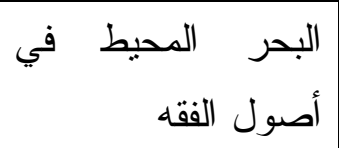 & I \\
\hline عفان ابن القيم، دار ابن & الجز ائري & القو اعد الفقهية & rr \\
\hline دار القلم، دمشق، طب، & الزرقا & شرح القو اعد الفقهية & r \\
\hline بيروت إحباء التراث العربي، & الجصاص أبو بكر محمد & أحكام القر آن & $\mu \varepsilon$ \\
\hline دار المعرفة צ191ام & أبو الوليد ابن رشد & بداية المجتهد ونهاية & ro \\
\hline عالم الكتب، الرياض، & محمد أمين بن عابدين & رد المحتار على الدر & Y \\
\hline الطباعة المنيرية، مصر ، & 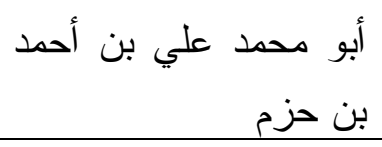 & المُحَلَّى & $r v$ \\
\hline دار القلم، دمشق، · . . بم & 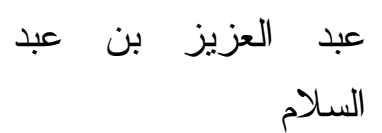 & الأحكام في مصالح & $\mu \wedge$ \\
\hline
\end{tabular}




\begin{tabular}{|c|c|c|c|}
\hline دار هجر، 997 ام & عبداله بن أحمد بن قدامة & روضنة الناظر وجنة & $r q$ \\
\hline 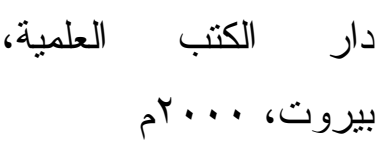 & عبدالرحمن بن أحمد & شرح العضد على المنتهى & $\varepsilon$. \\
\hline دار الصميعي، الرياض، & علي بن محمد الآمدي & الأحكام في أصول & $\leqslant$ \\
\hline 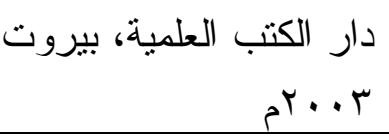 & علي بن محمد الآمدي & 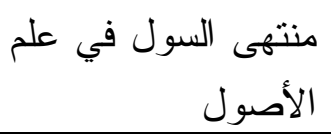 & $\varepsilon r$ \\
\hline دار الحديث، القاهرة & 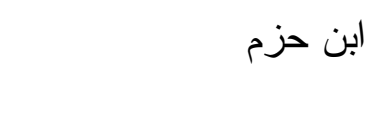 & الأحكام & $\varepsilon r$ \\
\hline بيروت، برار الكتب & ابن أمير الحاج & التقرير و التحبير & $\leqslant \varepsilon$ \\
\hline طؤسسة قرطبة، الجيزة، & عماد الدين أبي الفداء & تفسير القر آن العظيم & $\leqslant 0$ \\
\hline مؤسسة الرسالة، بيروت & محمد صدقي البرونو & موسو عة & $\leqslant 7$ \\
\hline مصرفى البابي الحلبي، & محمد أمين أمير بادشاه & تيسير التحرير & $\leqslant V$ \\
\hline دار المعرفة، بيروت & الأنصاري العلي محمد بن نظام & فو اتح الرحموت & $\leqslant \wedge$ \\
\hline 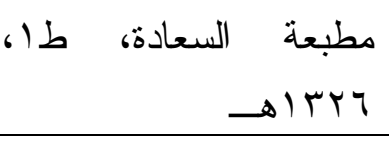 & جمال الدين ابن الحاجب & منتهى الوصول & $\leqslant 9$ \\
\hline 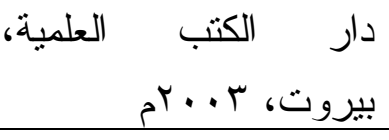 & تاج الدين السبكي & أصول الفقه امع في & 0 . \\
\hline مكة المكرمة، r +ـ اهـ & جلال الدين الخبازي & الفقه & 01 \\
\hline
\end{tabular}


د. نور علي محمود أحمد

\begin{tabular}{|c|c|c|c|}
\hline مؤسسة & السعدي عبدالرحمن بن ناصر & في تفير الكريم الرحمن كلام المنان & or \\
\hline مؤسسة الرسالة، بيروت & محمد بن جرير الطبري & 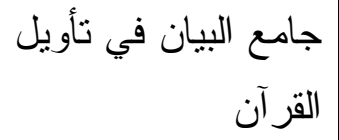 & or \\
\hline مكة المكرمة & د/ سليمان الصسادق البيرة & تأملات في الصلاة و فكانتها في & $0 \leqslant$ \\
\hline بيروت الكتب الإسلامية، & أبو الحسن الندوي & الأركان الأربعة & 00 \\
\hline دار الكتب العلمية & أبو إسحاق الثيرازي & الثافعي & 07 \\
\hline 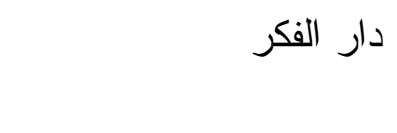 & أبو زكريا النووي & المجذبوع & $\Delta V$ \\
\hline دمثبعة الجامعة السورية، & الثيخ الزرقاء & المدخل الفقهي العام & $\Delta \wedge$ \\
\hline بيروت، بار الغرب الإسلامي، & التشيخ الزرقاء & شرح القو اعد الفقهية & 09 \\
\hline دار المعرفة، بيروت، طه & الثناطبي & المو افقات في أصول & 7. \\
\hline ع دار صادر، بيروت، & الغز الي & المستصفى & 91 \\
\hline طده & 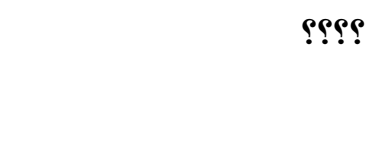 & 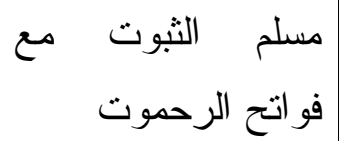 & Tr \\
\hline 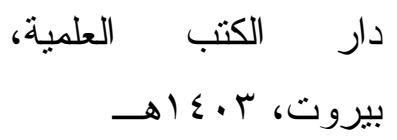 & ابن الحاجب المالكي & حاثية التفتاز اني & 4 \\
\hline
\end{tabular}




\begin{tabular}{|c|c|c|c|}
\hline 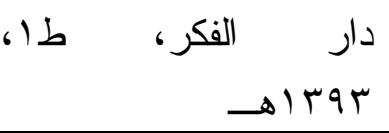 & أبو العباس القر افي & تتقيح الفصول & צ \\
\hline مطبعة السنة، القاهرة، & أبو البقاء ابن النجار & شرح الكوكب المنير & 70 \\
\hline ع عبادر، & 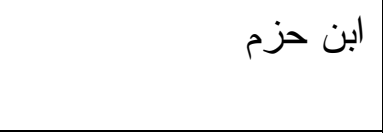 & مر اتب الإجماع & 79 \\
\hline دار المعرفة، بيروت & ابن حجر العسقلاني & تلخيص الحبير & TV \\
\hline القاهرة، Y Y I اهـ & ابن عبد البر & التمهيد لما في الموطأ & 71 \\
\hline ع دار الفكر، بيروت، & ابن قدامة & 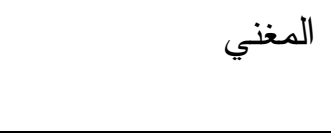 & 79 \\
\hline الحاج $\quad$ محرم أفندي & 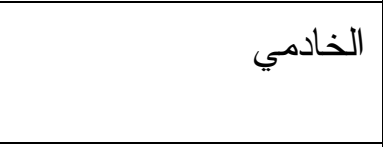 & 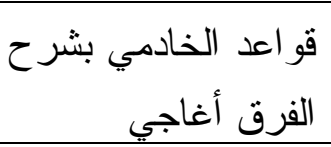 & v. \\
\hline 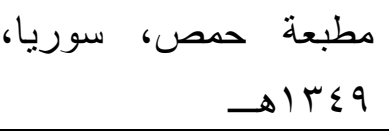 & ؟؟ & شرح الأتاسية العدلية مع & VI \\
\hline مؤسسة إهـ & ؟؟ & الوجيز في القو اعد & Vr \\
\hline دار الثماثـة، الخرطوم، السودان & الصـادق المهدي & جدلية & $v r$ \\
\hline دار المعرفة، بيروت، & 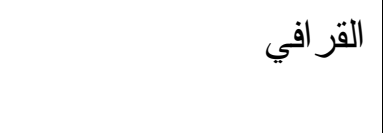 & الفروق & $V \varepsilon$ \\
\hline ط الأولى، 0. ع اهـ & محمد أمين الثنقيطي & مذكرة أصول الفقه & vo \\
\hline دار الكتب العلمية، بيروت & العز ابن عبد السـلام & قو اعد الأحكام في & VT \\
\hline مجلة الشريعة و الدر اسات & 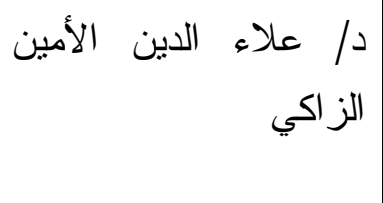 & فو اعد لضبط الاجتهاد & vV \\
\hline
\end{tabular}


د · نور علي محمود أحمد

\begin{tabular}{|c|c|c|c|}
\hline 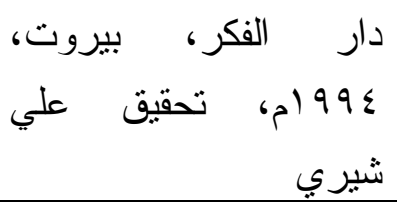 & مرتضى الزبيدي & 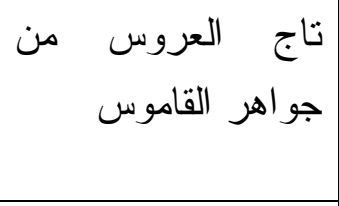 & $\vee \wedge$ \\
\hline القاهرة المنظمة العربية للتراث، & ابن سيده & الأعظم & $v q$ \\
\hline دار الكتب العلمية، بيروت & 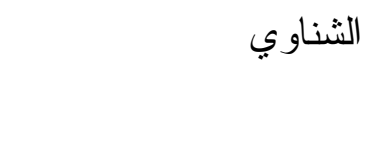 & إرشهال المدارك شر ح السالك & $\wedge$. \\
\hline مكتبة ز زلأز هران، خلف & محمد عرفة الدسوقي & حاثشية الدسوقي على الثرح الكبير & $\wedge 1$ \\
\hline دار الكتب العلمية، بيروت & الشيخ $\quad$ الصنيوني & 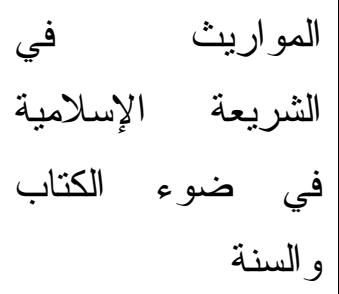 & $\wedge r$ \\
\hline بيروت & ابن العربي & أحكام القر آن & $\Lambda r$ \\
\hline بدون طبعة & دالغاصد بن محد & الفرائضة في علم & $\wedge \varepsilon$ \\
\hline دار الفضيلة & الجرجاني & معجم التعريفات & ^o \\
\hline دار المعرفة بيروت & السر خسي & أصبول الفقه $\quad$ في علم & $\wedge q$ \\
\hline 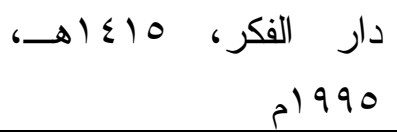 & أحمد غنيم & الفو اكه الدو اني & $\Lambda \vee$ \\
\hline مطبعة مصطفى الحلبي، & 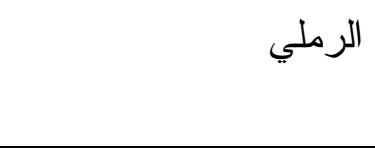 & شهاية المحتاج إلى المنهاج & $\wedge \wedge$ \\
\hline مكة مطعة الحكومة السعودية، & البهوتي & كثاف القناع & $\wedge 9$ \\
\hline
\end{tabular}




\begin{tabular}{|c|c|c|c|}
\hline دار الكتب العلمية، بيروت & علاء الدين الكاساني & بدائع الصنائع & 9 . \\
\hline المجمع الثقافي، أبو ظبي، & القاضي أحمد & قو القصاء & 91 \\
\hline دار الكتب العلمية، بيروت & عبد الله الموصلي & الاختيار & $q r$ \\
\hline دار المعرفة، بيروت، طن & زين الدنفي & 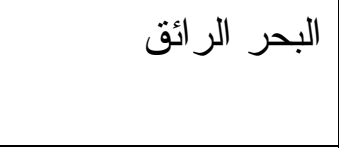 & $q 4$ \\
\hline لدار المعرفة، بيروت، & محمد رشيد رضـا & تقسير المنار & $9 \leq$ \\
\hline 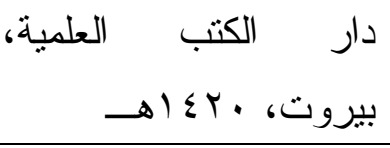 & الفيروز آبادي & القاموس المحيط & 90 \\
\hline دار الفضيلة & البغدادي صفي الدين & ومواعد الأصول & 99 \\
\hline جامعة إلمامية & الداية ـ أحمد الداية & 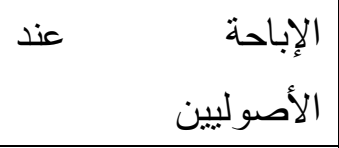 & $9 \vee$ \\
\hline دار الكتب العلمية، بيروت & الإسنوي & نهاية السول & $9 \wedge$ \\
\hline جاويد بريش، كر اتشي & 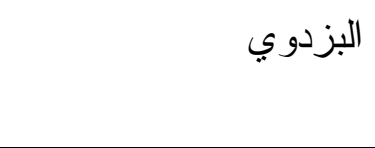 & كنز الوصرل إلى الأصول & 99 \\
\hline المكتبة العلمية، بيروت & أحمد بن محمد الفيومي & المصباح المنير & $1 \cdots$ \\
\hline تحقيق د د العبد اللطيف & الجويني - الجويني & الورقات & $1 \cdot 1$ \\
\hline ؟؟؟ & البيضـاوي & منهاج الوصول & $1 \cdot r$ \\
\hline مؤسسة الرسالة، بيروت & الإسنوي - جمال الدين & الفرويث في تخريج & $1 \cdot r$ \\
\hline
\end{tabular}


د. نور علي محمود أحمد

\begin{tabular}{|c|c|c|c|}
\hline مؤسسة الرسالة، بيروت & الصنعاني & بغية الأمل & $1 \cdot \varepsilon$ \\
\hline مكتبة العبيكان & ابن النجار & شرح الكوكب المنير & 1.0 \\
\hline دار ال الحديث، القاهرة، & 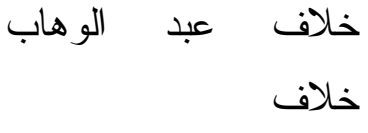 & علم أصول الفقه & .7 \\
\hline$؟$ & ؟ & الألصوليين $\quad$ الإباحة $\quad$ عند & $1 \cdot v$ \\
\hline عالم الكتاب، بيروت & القر افي شهاب الدين & 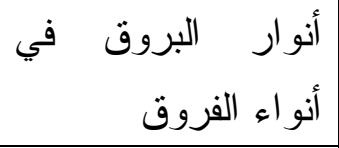 & $1 \cdot 1$ \\
\hline عالم الكتاب، بيروت & ابن الثاط & 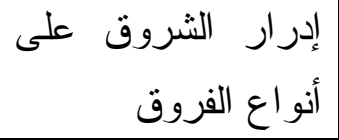 & 1.9 \\
\hline دار $\quad$ الكويت & خليل بن كيكلدي العلائي & تحقيق المر اد في أن & 11. \\
\hline دار الفكر، دمشق & العز ابن عبد السلام & 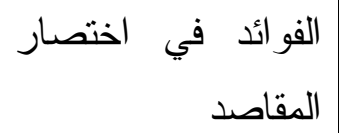 & 111 \\
\hline 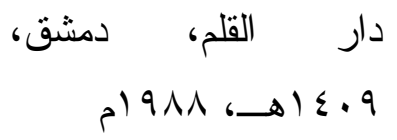 & البيانوني & الشريعة الإسلامية التكليفي في & $11 r$ \\
\hline الوفاء، & 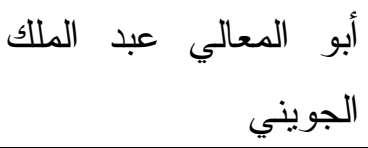 & 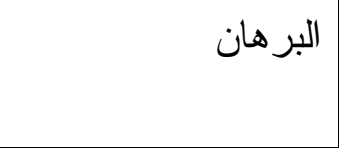 & $11 \%$ \\
\hline مؤسسة الرسالة، بيروت & محمود $\quad$ الزنجاني & تخريج الفروع علي & $11 \varepsilon$ \\
\hline دار الكتب العلمية، بيروت & عبدالرحمن الجزيري & الأربعة & 110 \\
\hline دار الكتب العلمية، بيروت & 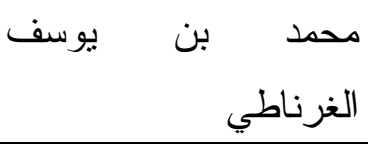 & التاج و الإكليل & 117 \\
\hline
\end{tabular}




\section{تطبيقات فقهية}

\begin{tabular}{|c|c|c|c|}
\hline دار الكتب العلمية ،بيروت & 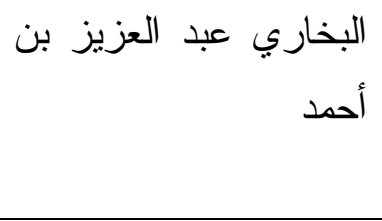 & 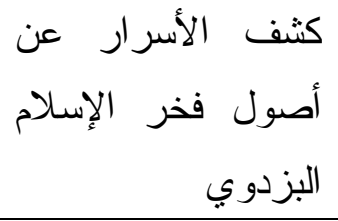 & $11 \mathrm{~V}$ \\
\hline دار الكتب العلمية & سعد الدين التفتاز اني & الفقيح في أصول & 111 \\
\hline مؤسسة & الطوفي & شرح & 119 \\
\hline
\end{tabular}

* * * 